\title{
Üniversite Öğrencilerinin Akademik Dinleme Becerileri Üzerine Bir Araştırma: Ders Ne Zaman Bitecek? Sıkıldım!
}

\author{
Deniz MELANLIOĞLU*
}

Öz

Bireyin gerek okul gerekse sosyal yaşamında en çok kullandığı dil becerisi olan dinleme, işitilen sesleri anlamlandırma ve bu anlamlandırma sonucunda bir tepkide bulunmadır. Okul hayatıyla birlikte dinleme becerisi sistemli bir şekilde geliştirilmeye çalışılmaktadır. Dinlemeye yönelik verilen eğitim öncelikle günlük iletişim odaklıyken daha sonra akademik dil ekseninde yürütülmektedir. Dolayısıyla zorunlu eğitimin sonunda öğrenciden beklenen etkin bir dinleyici kimliği kazanmasıdır. Ancak yapılan çalışmalar, çeşitli eğitim kademelerinde öğrencilerin pek çok dinleme problemi yaşadığı yönündedir. Bu çalışma, dinleme problemlerinden biri olarak nitelenen akademik dinleme becerisini üniversite öğrencileri özelinde ele almaktadır. Üniversite eğitimine devam eden öğrencilerin akademik dinleme becerilerindeki yeterlik düzeylerine iliş̧in algıları, nitel araştırma yöntemlerinden fenomenografi yardımıyla belirlenerek bir durum tespiti yapılması amaçlanmıştır. Verilerin toplanmasında yarı yapılandırılmış görüşme formu kullanılmış, analiz sürecinde ise içerik analizinden faydalanılmıştır. Buna göre araştırma bulguları; dikkatli dinleme süresi, akademik dinleme engelleri, dinleme verimliliği ve akademik dinleyici olma durumu olmak üzere dört ana başlık altında toplanmıştır. Araştırmada farklı alanlarda öğrenim gören üniversite öğrencilerinin akademik dinleme becerilerinin, dinleyiciye ve konuşmacıya bağlı faktörlerin yanı sıra dinleme ortamından da etkilendiği sonucuna ulaşılmıştır.

Anahtar Kelimeler: Dinleme becerisi, etkin dinleme, akademik dinleme, üniversite öğrencileri.

\footnotetext{
* Doç. Dr., Kırıkkale Üniversitesi Eğitim Fakültesi Türkçe Eğitimi Ana Bilim Dalı, Kırıkkale, Türkiye. Elmek: denizmelanlioglu@hotmail.com https://orcid.org/0000-0002-3663-0894
} 


\title{
A Study on University Students' Academic Listening Skills: When will the class be over? I am bored!
}

\begin{abstract}
Listening, which is the language skill most commonly used by individuals in both their school and social life, is making sense of the sounds heard and giving a reaction as a result of this. With the school life, listening skill is attempted to be systematically developed. The training given for listening is primarily focused on daily communication and then conducted on the basis of academic language. Therefore, at the end of compulsory education, what is expected of the student is to acquire an identity of an effective listener. However, studies show that students have many listening problems at various levels of education. The current study deals with the academic listening skill, which is described as one of the listening problems, in the context of university students. With the assistance of phenomenography, which is one of the qualitative methods, it was attempted to determine the competency level of the university students in academic listening skills. In the collection of the data, a semi-structured interview form was used and in the analysis process, content analysis was employed. In this connection, the research findings were grouped under four main headings: attentive listening time, academic listening barriers, listening efficiency and being an academic listener. In the study, it was concluded that academic listening skills of the university students studying in different fields were influenced by the listening environment as well as the factors associated with the listener and the speaker.
\end{abstract}

Keywords: Listening skills, active listening, academic listening, university students. 


\section{Extended Summary}

\section{Introduction}

Academic listening refers to one-way (operational) listening such as lectures or two-way (interactive) listening, such as dialogue between an instructor and a student in an academic setting (Lynch 2011). Brown and Yule (1983) argue that lessons are one-way (operational) listening-centred and that interactive listening is given little space. The reason for this can be explained by the fact that teachers generally prefer to use the method of lecturing (Çifçi 2001: 169). The existing research indicates that students spend approximately $50 \%$ of their time listening. There are various competencies needed for effective academic listening, such as determining the purpose or scope of the course, the ability to identify the current and subsequent topics of the course, and determining the relationship between the units during the conversation (Jordan 1997: 180). However, research on the extent to which students have these competencies is very limited. Competence in academic listening is very important for students who start or continue higher education. In professional knowledge-oriented universities, academic listening skills are vital to the student's future life. In this regard, the aim of the current study is to reveal the existing state by determining the university students' perceptions of their level of competence in academic listening skills.

\section{Method}

With the assistance of phenomenography, which is one of the qualitative research methods, it was attempted to reveal the existing state by determining the university students' perceptions of their level of competence in academic listening skills. A total of 112 students make up the study group of the current research. Of the participating students, $56(\% 50)$ are majoring in verbal disciplines while 56 (\%50) in numerical disciplines. The ages of the participants range from 18 to 27 and 59 of them are females and 53 are males. In the study group, there are 20 first year students, 28 second year students, 30 third year students and 34 fourth year students. In the collection of the data, a semi-structured interview form was used. The questions in the form are given below: 
1. How long can you listen attentively within a class hour? Can you explain it with its reasons?

2. What kind of obstacles to your listening do you think you encounter during the lesson? Can you share your opinions about this?

3. How do you think the efficiency of listening to the lesson can be enhanced?

4. Do you think that you have the academic listening skill? Can you explain its reasons?

The interviews conducted with the participating students lasted for 20 to 25 minutes. Collection of the research data was completed within 42 days. In the data analysis process, content analysis method was used.

\section{Result and Discussion}

In the current study aiming to investigate the university students' perceptions of the level of competence in their academic listening skills, the following results have been derived from the data collected from 112 university students:

1. The participants' time of attentive listening to a lesson varies between 10 and 50 minutes. The factors affecting the attentive listening process were found to be distraction of the attention, interest in the course, physical and psychological needs of the listener, lesson process and environment.

2. According to the participants, obstacles to listening that hinder academic listening skills are environment, teacher, peers, physical needs, subject of the lesson and out-of-class applications.

3. The participants' suggestions for increasing the efficiency of academic listening can be listed as follows:

a. The teacher responsible for the course should ensure teacher-student interaction.

b. With various materials suitable for the content of the course, the teaching of the subject should be enhanced.

c. The lessons should be delivered not to convey theoretical knowledge but to provide opportunities to practice for students in compliance with the nature of the subject.

d. The information presented in the lesson should be related to daily life.

e. Students should be given strategy training for listening. The student 
should be able to select the strategy that will serve his/her purpose and use it during the lesson.

f. The presentation of new information should be built on the student's prior knowledge.

1. The participants generally see themselves incompetent in terms of their level of academic listening skill. There are only 14 university students thinking that they are competent in listening. The research findings were collected under four headings: attentive listening time, academic listening barriers, listening efficiency and being an academic listener.

In the current study, listening skill was addressed from the academic listening dimension and the university students' level of competence in academic listening was presented together with their self-awareness. As a result of the findings of the current study, it can be argued that the students' level of academic listening is inadequate. This can be interpreted as negative in terms of the development of listening skill, social interaction etc. To eliminate this negativity, following suggestions can be made:

2. Students do not receive any training to develop their academic listening skill. The development of this skill is left to chance. From the first year of university education onwards, each student should be given an academic listening course.

3. An anticipated learning outcomes table showing what is expected of students in terms of academic listening should be prepared.

4. Although the factors that affect the academic listening process are known, in order to determine the effect of these factors, diversified scales should be prepared and applied in terms of the sub-dimensions of "Lesson Listening Barriers".

4. Experimental studies on the subject should be conducted and efficient alternative ways to affect the process should be introduced to the literature.

5. Because of the university exam system, students are placed in their preferences only according to their performance in reading skills. This makes listening, speaking and writing skills less important. It is thought that an examination system that measures all four skills will support the development of academic listening. 



\section{Giriş}

"Nasll bir dinleyici olduğunuzu düşünüyorsunuz?" sorusuna hiç düşünmeden pek çok öğrencinin vereceği cevap “İyi bir dinleyiciyim.” olacaktır. Ancak bu cevabın nedenleri sorgulandığında tutarlı gerekçelerin sıralanacağını söylemek pek mümkün gözükmemektedir. Özellikle cep telefonları vasıtasılla kurulan sanal dünya neticesinde yüz yüze iletişimi sürdürmenin günümüzde imkânsız bir hâle gelmesi öğrencilerin iletişime "mış gibi" yaklaşmalarına neden olmaktadır. Görünüşü ile gerçeği aynı olmayan, görünüşü başka aslı başka olan şeyler için kullanılan (Cüceloğlu 2011: 19), "mış gibi” kavramı iletişim engellerinin başında gelmektedir. Bu durum, bireyler arasında "iletişim yoksunluğu" veya "iletişim kopukluğu" meydana getirmektedir.

İletişimin; bir gönderici tarafından öte yandaki bir alıcı üzerinde belirli bir etki yaratmak amacıyla adına gösterge denilen anlam yüklü birimlerden yararlanarak karşı tarafa belirli bir bildiri ulaştırılması eylemi (Başkan 2003: 15) olduğu dikkate alındığında anlama ve anlatma olmak üzere iki boyutlu bir sürecin söz konusu olduğu anlaşılmaktadır. Bu bağlamda sözel (dinleme-konuşma) ve yazılı (okuma-yazma) olmak üzere iki tür iletişimden bahsedilebilir. Günlük hayat dikkate alındığında iletişimin daha çok sözel iletişim odağında gerçekleştiği söylenebilir. Yapılan araştırmalarda da iletişim sürecinde dinlemeye \%40, konuşmaya $\% 35$, okumaya $\% 16$, yazmaya ise $\% 9$ oranında yer verildiği ifade edilmektedir (Burley-Allen 1995). Peterson ve Karschnik (2011) de bireylerin günlük hayatlarının \%55'ini dinlemeye ayırdıklarını dile getirmektedir. Tompkins (1998) ise bireyin diğer becerilere harcadığı toplam zaman kadar bir süreyi dinlemeye ayırdığını belirtmektedir. Bu nedenle Egan (2001)'a göre iletişimin sağlıklı bir şekilde başlatılması, sürdürülmesi ve sonlandırılması için gereken temel beceri konuşma, okuma ve yazmadan ziyade dinlemedir.

Dinleme; işitsel bir girdiyi anlamlandırmak (Brown 2011: 5); iletişim durumlarında dilin sinyal unsurlarının tanınmasının kontrolünü üstlenme (Lado 1961: 206); kişinin tercihine bağlı olarak seçerek ve isteyerek algıladığı sesler 
bütünü (Özbay 2005: 55), işittiğini anlamak amacıyla dikkat harcamak ve bir sonuç çıkarmak için konuşmayı izleme (Göğüş 1978: 228), sözlü iletişim sürecinde konuşan tarafından ses birimleri vasıtasıyla gönderilen mesajların alıcı kişinin zihninde deşifre edilip bilgiye dönüştürüldüğü zihinsel bir süreç (Onan 2005: 157) olarak tanımlanmaktadır. Çeşitli araştırmacılar tarafından farklı yönleri vurgulanan dinleme, iletişim sürecinde işitilen sesleri anlamlandırma ve bu anlamlandırma sonucunda bir tepkide bulunma şeklinde kısaca açıklanabilir (Melanlığlu 2012). Purdy (1997: 60-61)'e göre dinleyici sosyokültürel-dilsel çevreyi içine alıp sürekli emdiği için dinleme, sözlü ve/veya sözsüz mesajlardan anlam kurma ve cevap verme sürecinden çok daha fazlasını içermektedir. Bu sürecin temel niteliği ise fiziksel (dinlemenin gerçekleşmesi, duyma ve işitme farkı), zihinsel (anlama, yorumlama ve iletişim) ve psikolojik olmak üzere çok yönlü olmasidir.

Hyslop (1988), bütün başarılı insanların gerçekte iyi bir dinleyici oldukları, dinlemenin insanlar arasında anlaşmayı kolaylaştırdığı, insanların birbirlerine olan saygı ve sevgiyi en üst düzeye çıkardığını söylemektedir (aktaran; Umagan 2007: 151). Cihangir (2004: 11) de olumlu ilişkiler geliştirmede, insanlardan bilgi almada, başkalarını tanımada, anlamada ve onlara yardım etmede en temel unsurun dinleme olduğunu ifade etmektedir. Ancak Robertson (2004: 57), insanların yeterli dinleme verimliliğine sahip olmadığını vurgulamaktadır. Çünkü bir başkasını dinlemek, dinleyebilmek güç bir iştir; muhataba saygı duymayı, sabırlı ve rahat olmayı gerektirir. Bu anlamda Cüceloğlu (2016), konuşma becerisini geliştirmek için çeşitli kurslar düzenlendiğine ancak bunun bir parçası olan dinlemeye ilişkin daha iyi olma yönünde herhangi bir çabanın sarf edilmediğine dikkat çekmektedir. Oysa evde, okulda, çarşıda, pazarda, tiyatroda vb. dinleme faaliyetiyle sürekli iç içe olan birey için dinleme bilgi edinmenin, öğrenmenin, etkileşim kurmanın başlıca yollarından biridir.

Dinleme becerisine yönelik verilen eğitimin iletişim çatışmalarını ve iletişim yoksunluğunu önlediği bilinmektedir (Moorhead-Winefield 1991). Öyle ki dinleme eğitimi almamış birey, dinlediği şeylerin ancak dörtte birini hatırlayabilmektedir (Yalçın 2002: 128). Gordon (1993), bireye dinlemeye yönelik eğitim verildiğinde becerideki yetkinliğini, günlük yaşama taşıyabileceğini böylelikle 
kendinden kaynaklanabilecek iletişim çatışmalarının önüne geçebileceğini dile getirmektedir. Dökmen (1994) de verilecek eğitimle bireye yanlış dinleme davranışları fark ettirilirse (karşısındakinin sözünü kesme, dikkatini dağıtma vb.) bunların olumlu yönde değişim gösterebileceğini ifade etmektedir.

Dinleme becerisinin geliştirilmesine yönelik eğitim faaliyetleri, her ne kadar okul öncesi eğitimi ile başlamakta ise de okul öncesi eğitimin tercihe bağlı olması nedeniyle dinleme eğitiminin genel anlamda ilkokul dönemi ile sistemli bir şekilde yürütüldüğü söylenebilir. İlkokul ve ortaokulda Türkçe dersleri kapsamında verilen bu eğitim, ortaöğretimde dil dersleri ile pekiştirilmektedir. Buna göre zorunlu eğitimi bitiren öğrenciden dinleme becerisini Türk millî eğitiminin öngördüğü doğrultuda geliştirmesi ve etkili dinleme becerisini alışkanlığa dönüştürmesi beklenmektedir. Elbette bu eğitim sürecinde öğrencilerin dinleme eğitiminde gösterdikleri başarının aynı olmasını beklemek bir yanılgı olarak değerlendirilebilir. Farklı biyolojik yapılara sahip ve farklı kültürel çevrelerden gelen öğrencilerin karşılaştıkları durumlara yönelik gösterdikleri tepki aynı olamaz. Öğrencilerin geçmiş deneyimleri, ön bilgileri, ilgileri, ihtiyaçları, yetenekleri, öğrenme stilleri gibi pek çok etmen gösterilen tepkinin niteliğini belirleyen değişkenlere dönüşmektedir. Her birinin dinleme eğitiminde kat ettiği yol da bu unsurlara göre farklılaşmaktadır. Bu nedenle eğitim kurumlarında dinleme becerisi birtakım kazanımlar üzerine kuruludur. Bunların her öğrencide gerçekleştirilmeye çalışılması dinleme becerisinin gelişimine olumlu katkı sağlayacaktır. Oğuzkan (1965: 29), dinleme eğitiminin faydalı olabilmesi, amaca ulaşabilmesi için uyulması gereken ilkeleri şu şekilde sıralamaktadır:

- Küçük yaşlardan itibaren eğitimine başlanmalıdır.

- Okulun ve öğretim programının çizdiği yol haritasına göre süreç planlanmalıdır.

- Etkin bir dinleyici niteliği gösteren öğretmenler rehberliğinde sürdürülmelidir.

- Kullanılan öğretim yöntem ve teknikleri, içeriğe uygun olarak çeşitlenmelidir.

- Modern ve güncel öğretim araçlarından yararlanılmasına dikkat edilmelidir. 
Göğüş (1978: 227-228) okullarda sistemli bir şekilde verilen dinleme eğitiminin başlıca amacının, işitme duyusunu öğrenmenin bir parçası hâline getirmek olduğunun ifade ederek bu amacın ayrıntılarını şu şekilde özetlemektedir:

- Kaynaktan gelen mesajı tam olarak anlamak için dinleyebilmek.

- Çeşitli dinleme ortamlarında nezaketle dinleme alışkanlığı kazanmak.

- Bilgi, düşünce, haber almak için dinleyebilmek.

- Boş zamanlarda müzik dinlemeye alışmak, tiyatro, sinema, radyo ve televizyondan yararlanmak için kesintisiz bir dinleme alışkanlığı kazanmak.

- Dinledikleri arasında sıra veya neden sonuç ilgisi kurma yeteneği kazanmak.

- Dinlediği konuşmanın ana düşüncesini kavramaya çalışmak.

- Dinlediğini değerlendirirken önyargılardan, kişisel sevgi ve karşıtllk duygusundan siyrilabilmek, tarafsiz olabilmek.

- Dinlediğinin eksik, yanlış, abartıll, gerçek, yararlı, yararsız vb. yönlerini seçmeyi öğrenebilmek.

- Dinlediğini değerlendirme yeteneği kazanmak.

Dinlemeye yönelik verilen eğitimde sıralanan maddelerde karşılaşılan eksiklikler birer dinleme engeline dönüşecek, bu durum zamanla dinleme kaygısına ve dinlemeye yönelik olumsuz tutum geliştirmeye neden olacaktır. Dolayısıyla dinleme eğitiminde öğrenci kaynaklı sorunların ortaya konması, onların farklı eğitim kademelerinde etkin dinleyici olabilmelerini sağlamanın yanında sağlıklı iletişim kurabilen bir toplumun var olabilmesi için de bir ön koşuldur, denilebilir. Öğretmenler tarafindan ilkokul ve ortaokul düzeyinde derste parmak kaldırmadan veya söz istemeden konuşmanın dinleme konusunda ilk sırada yer alan istenmedik öğrenci davranışı olduğu bilinmektedir (Balay ve Sağlam, 2008; Tolunay Kapucuoğlu, 2008). Özgözgü (2007) lise öğrencilerinin arkadaşları ile konuşma, dersi dinlememe, izin almadan konuşma gibi davranışları çok sık tekrarladıklarını belirtmektedir. Ayrıca derste birbirleriyle konuşmak, dersin akışını isteyerek bozmak gibi dinleme sürecini olumsuz etkileyen çeşitli davranışların varlığı da dikkat çekmektedir (Danaoğlu 2009). Günlük yaşamda olduğu gibi okul hayatının da önemli bir bölümünün dinlemeyle geçtiği düşünüldüğünde dinleme kurallarını bilmeme ile başlayan silsilenin daha büyük sorunlara yol açacağı açıktır ki gerek 
okul gerekse toplum odaklı iletişim çatışmalarına bakıldığında temel sorunun insanların birbirini dinlemelerinden kaynaklandığ meme ya da eksik dinlemenin sonuçları ise şunlardır:

- Konuşan, dinleyicinin ilgisizliği karşısında konuşma motivasyonunu kaybeder. Dikkati çekmek için sesinin tonunu yükseltir. Bu çaba konuşmaciyı yorar.

- Dinleyici, konuşanın amacını anlayamaz. Bilgileri, yanlış veya eksik edinir.

- Kötü dinleme sonucu edinilen yanlış ya da eksik bilgiler, davranışlarda da hatalara neden olur.

- Konuşmayı dinlemek istemeyen, başka uğraşılar içine girer. Bu da düzen ve gürültü sorununa yol açar.

- Kötü dinleme, ana dili becerilerinin gelişimini engeller (Göğüş 1978: 230).

Belirtilen sonuçlar incelendiğinde dinlemeye yönelik verilen eğitimin içeriği de ortaya çıkmaktadır. Okul dönemi içerisinde öğrencilerin dinleme süreçlerinin sadece Türkçe dersi ile sınırlı olmadığı dikkate alındığında onların okul yaşamlarında öncelikle akademik dinleme konusunda farkındalık kazanmaları gerektiği söylenebilir. Derse yönelik dinleme bilgi için dinlemeyi gerekli kılmaktadır. Tompkins (2005: 312), bu dinleme türünde dinleme amacının belirlenmesi, ana ve yardımcı fikirlerin bulunması, elde edilen bilgilerin beyinde organize edilmesi gibi ögelerin gerçekleşmesi gerektiğini söylemektedir. Özbay (2009: 113), eğitim kurumlarında bilgi için dinlemeye yönelik herhangi bir eğitimin verilmediğini; sıralanan bu unsurların ise "Susun!”, “Konuşmayın!", "Dinleyin!” ifadeleriyle sağlanmaya çalışıldığını dile getirmektedir. Bu tutum, akademik dinlemenin gelişmesini engelleyen ana etmenlerden biri olarak düşünülmektedir.

Akademik dinleme, dersler gibi tek yönlü (işlemsel) dinleme veya akademik ortamdaki bir eğitmen ve öğrenci arasındaki diyalog gibi iki yönlü (etkileşimli) dinleme anlamına gelmektedir (Lynch 2011). Brown ve Yule (1983) derslerin tek yönlü (işlemsel) dinleme odaklı olduğunu, etkileşimli dinlemeye oldukça az yer verildiğini söylemektedir. Bu durumun nedeni, öğretmenlerin genellikle düz anlatım yöntemini kullanmayı tercih etmesi ile açıklanabilir (Çifçi 2001: 169). Okul döneminde öğrenciler, bilgilerin büyük bir kısmını dinleyerek öğrenmektedir. Temur (2001: 62) çocuğun okula başladığında sınıf içindeki zamanının ortalama \% 60'ını dinlemekle geçirdiğini söylemektedir. Yangın (1999: 30) ise 
bir ders saatinin \% 67'sinin sözlü davranışlara ayrıldığını; öğrencilerin okulda öğretmen ve akranlarını 2,5 ila 4 saat arasında dinlediklerini açıklamaktadır. Robertson (2004), günlük yaşamlarında ilkokul öğrencilerinin \%57'lik, üniversite öğrencilerinin ise \%53'lük bir zaman dilimini dinleyerek geçirdiklerini vurgulamaktadır. Belirtilen araştırma bulguları, öğrencilerin akademik başarılarının büyük oranda dinlemeye dayalı olduğunu göstermektedir. Bu nedenle yeterli düzeyde akademik dinleme becerisine sahip olmak bir gerekliliktir. Özellikle mesleki bilginin sunulduğu yükseköğretim kademesinde akademik dinleme, öğrencinin temel gereksinimlerinden biri hâline dönüşmektedir. Çünkü öğrencinin bir ders saati süresi içinde dinleyerek ve izleyerek öğrenebileceği bir konuyu, ders dışında kendi başına çalışarak gereğince öğrenebilmesi için gereken süre, dersin özelliğine göre değiş̧mekle birlikte en az üç ders saatine eşittir (Uluğ 1995: 70). Bu oran, akademik dinlemenin öğrenci açısından önemini göstermesi bakımından dikkate değerdir.

Dinleme becerisi, okul başarısını birebir etkilediği için bazı araştırmacılar (Flowerdew 1995; Vandergrift 2007), akademik dinleme ile iletişimsel dinleme kavramlarını birbirinden ayırmaktadır. Birey, iletişimsel dinlemeyi, günlük hayatında çevresiyle iletişim kurarken (Cramer, 2004, s. 138) akademik dinlemeyi ise ders veya herhangi bir akademik ortamda etkileşim içindeyken kullanmaktadır. Flowerdew (1995: 11) ve Richards (1983)'a göre akademik dinleme ve iletişimsel dinleme becerisi arasında birtakım farklar bulunmaktadır:

- Akademik dinlemede dinleyici, dersin konusunu kolayca anlayabilmek için ön bilgiye ihtiyaç duyarken iletişimsel dinlemede bu tür bir ön bilgiye ihtiyacı yoktur.

- Akademik dinlemede dinleme amacına göre sunulan bilgiyi ihtiyacı doğrultusunda ayıklaması gerekirken iletişimsel dinlemede dinleyicinin bunu her zaman yapması gerekmez.

- Konuşmanın dolaylı veya doğrudan ilerlemesi, akademik dinlemeyi sekteye uğratmazken iletişimsel dinlemede süreç kesintiye uğrayabilir.

- Akademik dinlemede dinleme süresi uzasa dahi dinleyici bu süreci verimli şekilde geçirebilir ancak iletişimsel dinlemede bu mümkün değildir. 
- İletişimsel dinlemede dinleme stratejilerini kullanmaya çoğu zaman ihtiyaç duyulmazken akademik dinlemede bu stratejiler bir zorunluluğa dönüşür (not alma vb.).

Görüldüğü gibi akademik dinlemenin niteliği birçok değişkenle doğrudan ilgili olup (Aryadoust, Goh vd. 2012: 223) bu unsurlar dinleme becerisinin gelişiminde belirleyici rol üstlenmektedir. Dersin amacını veya kapsamını belirleme becerisi, dersin konusunu ve takip eden konuları belirleme becerisi ve konuşma esnasında birimler arasındaki ilişkiyi belirleme gibi akademik dinlemeye ait başka niteliklerin olduğu da ifade edilebilir (Jordan 1997: 180). Akademik dinlemedeki yetkinlik yükseköğretime başlayan veya devam eden öğrenciler için oldukça önem taşımaktadır. Mesleki bilgi odaklı üniversitelerde akademik dinleme becerisi öğrencinin gelecek yaşantısı için hayati bir öneme sahiptir. Bu noktadan hareketle çalışmanın amacı, üniversite eğitimine devam eden öğrencilerin akademik dinleme becerilerindeki yeterlik düzeylerine yönelik algılarını belirleyerek bir durum tespitinde bulunmaktır.

\section{Yöntem}

Üniversite öğrencilerinin akademik dinleme becerilerine yönelik bir bak1ş açısı sunmayı amaçlayan bu araştırmada grup içerisindeki bireylerin ön bilgilerinden hareketle olgulara verdikleri anlamları paylaşmaya odaklanan nitel araştırma yöntemi, fenomenografi kullanılmıştır. Fenomenler hakkında kişilerin yaşanmışlıklarına, algılarındaki farklılıklara odaklanan ampirik bir çalışma yöntemi olan fenomenografide bireysel farkl1lkklar nedeniyle fenomenlerin tanımlanma biçimleri farklılık göstermektedir. Yıldırım ve Şimşek (2008: 75)'e göre fenomenografi, nitel araştırmanın doğasına uygun olarak kesin ve genellenebilir sonuçlar ortaya koymamaktadır fakat bir olguyu daha iyi tanımaya ve anlamaya yardımcı olacak sonuçlar sağlayacak örnekler, açıklamalar ve deneyimler sunmaktadır.

\section{Çalışma Kümesi}

Fenomenografi araştırmalarında veri kaynakları, araştırmanın odaklandığı olguyu yaşayan ve bu olguyu dışa vurabilecek veya yansitabilecek bireyler veya 
gruplardır (Yıldırım-Şimşek 2008: 74). Üniversite öğrencilerinin akademik dinleme becerilerindeki yeterlik düzeylerine yönelik algılarını ortaya koyabilmek için 112 öğrenci bu araştırmanın çalışma kümesini oluşturmaktadır. Çalışma kümesini belirlemede kolay erişebilirlik ve gönüllülük esas alınmıştır. Çalışma kümesinde yer alan katılımcıların 56 (\%50)'sı sözel 56 (\%50)'sı sayısal alanlarda öğrenim görmektedir. Sözel bölümler; fen edebiyat fakültesinden sosyoloji, tarih, Arapça mütercim tercümanlık; iktisadi ve idari bilimler fakültesinden uluslararası ilişkiler; eğitim fakültesinden psikolojik danışmanlık ve rehberlik ile Türkçe öğretmenliği ve hukuk fakültesidir. Sayısal bölümler; mühendislik fakültesinden inşaat mühendisliği, biyomühendislik, makine mühendisliği; veterinerlik fakültesi, diş hekimliği fakültesi, sağlık bilimleri fakültesi ve hemşireliktir. Araştırmaya her bir bölüm kapsamından 8'er öğrenci dâhil edilmiştir. Yaş aralığ 18 ile 27 arasında değişen katılımcılardan 59 (\%53)'u kız, 53 (\%47)'ü erkektir. Çalışma kümesinde 1. sinıftan 20 (\%18), 2. sinıftan 28 (\%25), 3. sinıftan 30 (\%27), 4. sinıftan 34 (\%30) öğrenci yer almaktadır.

\section{Verilerin Toplanması}

Araştırmada veri toplama aracı olarak görüşmeden yararlanılmıştır. Olgulara ilişkin yaşantıları ve anlamları ortaya çıkarmak için görüşmenin araştırmacılara sunduğu etkileşim, esneklik ve sondalar yoluyla irdeleme özelliklerinin kullanılması gerekmektedir (Yıldırım-Şimşek 2008: 74). Bu nedenle araştırmada veri toplamak amacıyla yarı yapılandırılmış görüşme formu kullanılmıştır. Görüşme formunda bulunan sorular öncelikle araştırmacı tarafından hazırlanmış ve akademik dinleme becerisine içerik açısından uyumu iki alan uzmanı tarafindan değerlendirilmiştir. Uzmanların olumlu ortak kanı belirttikleri toplam dört (4) soru görüşme formuna alınırken içerik olarak benzer hususlara odaklanan üç soru görüşme formundan çıkarılmıştır.

İçerik ve araştırma amacına uygunluğu açısından değerlendirilen görüşme formu için bir ön uygulama yapılmıştır. Görüşme soruları öncelikle çalışma grubunda olmayan sözel ve sayısal alan ayrımına dikkat edilerek beşer öğrenciye uygulanmıştır. Elde edilen veriler doğrultusunda alan uzmanları ile görüşme formu tekrar gözden geçirilmiş ve forma son şekli verilmiştir. Görüşme formundaki sorular şu şekildedir: 
1. Bir ders süresince ne kadar dikkatli dinleyebilirsiniz? Nedenleriyle açıklayabilir misiniz?

2. Ders sürecinde ne tür dinleme engelleri ile karşılaştığınızı düşünüyorsunuz? Bu konudaki görüşlerinizi paylaşır mısınız?

3. Sizce ders dinleme verimliliği nasll artırlabilir?

4. Akademik dinleme becerisine sahip olduğunuzu düşünüyor musunuz? Nedenleriyle açıklar misınız?

Çalışma grubunun büyüklüğü dikkate alındığında araştırmacı, görüşmelerini öğrencilerden randevu alarak üniversite kantini, fakültelere ait derslik, kütüphane, yurt kantini gibi üniversite bünyesindeki farklı mekânlarda gerçekleştirmiştir. Öğrencilerden görüşmelerin ses kayıt cihazıyla kaydedilebilmesi için izin istenmiş, müsaade eden öğrencilerin görüşmeleri böylece kayıt altına alınırken izin vermeyen öğrencilerden toplanan veriler araştırmacı tarafından not edilmiştir. Görüşmeler ortalama 20 ila 25 dakika aralığında sürmüştür. Araştırma verilerinin toplanmas 12 gün sürmüştür.

\section{Verilerin Analizi}

$\mathrm{Bu}$ çalışmanın verileri fenomenografi yöntemine uygun olarak toplanmış ve verilerin analizi sürecinde içerik analizinden faydalanılmıştır. Analiz sürecinde bir alan uzmanı ve araştırmacı birlikte çalışmışır. Bu tür araştırmalar, yaşantıları ve anlamları ortaya çıarmaya yönelik olduğu için yapılan içerik analizinde verinin kavramsallaştırılması ve olguyu tanımlayabilecek temaların ortaya çıkarılabilmesi amaçlanmaktadır (Yıldırım-Şimşek 2008: 75).

Öncelikle ses kaydına dayalı görüşme kayıtları üç kez listelenmiştir böylece güvenilir kayıtlar elde edilmeye çalışılmıştır. Ses kaydına dayalı olmayan veriler ise yeniden gözden geçirilerek hiçbir müdahalede bulunulmadan yeniden yazılmıştır. Daha sonra elde edilen veriler gruplandırılıp son metindeki anlam kategorileri analiz edilmiştir. Gruplamalardan sonra kategoriler arasında kıyaslamalar yapılmıştır. Uzman ve araştırmacı tarafından ulaşılan kategoriler böylece son hâlini almıştır. Ana anlamlar etiketlenmiş, kavramlar gruplanıp kategorize edilmiş ve kategorilere isimler verilmiştir. Kategorilerin belirlenmesinden sonra tablolar oluşturulmuş ve kategorilere örnek olabilecek cümlelerle tablolar zenginleştiril- 
miştir. Çalışmaya katılan 112 öğrenciye isimlerine ve cinsiyetlerine bakılmaksızın devam ettikleri bölümler dikkate alınarak numaralar verilmiştir. Buna göre verilen kodlar şu şekilde ifade edilebilir:

Tablo 1. Çalışma Kümesindeki Katılımcılara Alanlarına Göre Verilen Kodlar

\begin{tabular}{|c|c|c|}
\hline Alan & Bölüm adı & Kodu \\
\hline \multirow{7}{*}{ Saytsal } & İnşaat Mühendisliği & İK1, İK2, İK3, İK4, İK5, İK6, İK7, İK8 \\
\hline & Biyomühendislik & $\begin{array}{l}\mathrm{BK} 1, \mathrm{BK} 2, \mathrm{BK} 3, \mathrm{BK} 4, \mathrm{BK} 5, \mathrm{BK} 6, \\
\mathrm{BK} 7, \mathrm{BK} 8\end{array}$ \\
\hline & Diş Hekimliği & $\begin{array}{l}\text { DK1, DK2, DK3, DK4, DK5, DK6, } \\
\text { DK7, DK8 }\end{array}$ \\
\hline & Veterinerlik & $\begin{array}{l}\text { VK1, VK2, VK3, VK4, VK5, VK6, } \\
\text { VK7, VK8 }\end{array}$ \\
\hline & Sağlık Bilimleri Fakültesi & $\begin{array}{l}\text { SAK1, SAK2, SAK3, SAK4, SAK5, } \\
\text { SAK6, SAK7, SK8 }\end{array}$ \\
\hline & Hemşirelik & $\begin{array}{l}\text { HEK1, HEK2, HEK3, HEK4, HEK5, } \\
\text { HEK6, HEK7, HEK8 }\end{array}$ \\
\hline & Makine Mühendisliği & $\begin{array}{l}\text { MK1, MK2, MK3, MK4, MK5, MK6, } \\
\text { MK } 7, \text { MK } 8\end{array}$ \\
\hline \multirow{7}{*}{ Sözel } & Sosyoloji & $\begin{array}{l}\text { SK1, SK2, SK3, SK4, SK5, SK6, SK7, } \\
\text { SK8 }\end{array}$ \\
\hline & Tarih & $\begin{array}{l}\text { TK1, TK2, TK3, TK4, TK5, TK6, TK7, } \\
\text { TK8 }\end{array}$ \\
\hline & Arapça Mütercim Tercümanlık & $\begin{array}{l}\text { AK1, AK2, AK3, AK4, AK5, AK6, } \\
\text { AK7, AK8 }\end{array}$ \\
\hline & Uluslararası İlişkiler & $\begin{array}{l}\text { UK1, UK2, UK3, UK4, UK5, UK6, } \\
\text { UK7, UK8 }\end{array}$ \\
\hline & Türkçe Öğretmenliği & $\begin{array}{l}\text { TÜK1, TÜK2, TÜK3, TÜK4, TÜK5, } \\
\text { TÜK6, TÜK7, TÜK8 }\end{array}$ \\
\hline & Psikolojik Danışmanlık ve Rehberlik & $\begin{array}{l}\text { PK1, PK2, PK3, PK4, PK5, PK6, PK7, } \\
\text { PK8 }\end{array}$ \\
\hline & Hukuk Fakültesi & $\begin{array}{l}\text { HK1, HK2, HK3, HK4, HK5, HK6, } \\
\text { HK7, HK8 }\end{array}$ \\
\hline
\end{tabular}

Bulgular bölümündeki tablolarda bulunan kategorilerin ve örnek konuşma cümlelerinin yanında bulunan numaralar katılımcılara ait Tablo 1'de verilen kodlardır. 


\section{Bulgular ve Yorum}

Görüşme formunda bulunan sorulara katılımcıların verdikleri cevaplar doğrultusunda çalışmada aşağıdaki bulgulara ulaşılmıştır.

Tablo 2. Katılımcıların Dikkatli Dinleme Sürecini Etkileyen Unsurlar

\begin{tabular}{|c|c|c|}
\hline Tema & Ífade edilen & Katılanlar \\
\hline 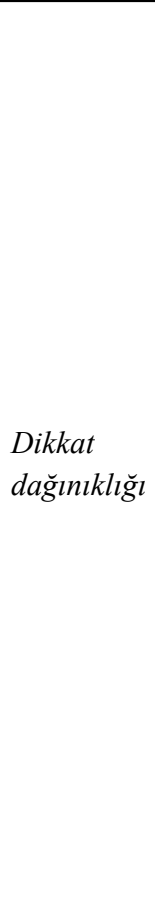 & $\begin{array}{l}\text { Ders süresince en fazla } 20 \text { dakika kadar dikkatli } \\
\text { dinleyici olabiliyorum. Çünkü daha çok dinleye- } \\
\text { rek anlayarak bir insan değil, bireysel çalışarak } \\
\text { anlayan bir insanım. (HK7) } \\
\text { Derse ne kadar ilgili olursam olayım hocanın tak- } \\
\text { tığı küpe bile benim dikkatimin dağılmasına sebep } \\
\text { olabiliyor. (SAK3) } \\
20 \text { dakika. Çünkü bir yerde okumuştum insanın } \\
\text { dikkati } 20 \text { dakika sonra dağılırmış. Ama gerçekten } \\
\text { de büyük bir heves ve öğrenme isteğiyle girdiğim } \\
\text { derslerde en fazla } 30-40 \text { dakika sonra bir ayağa } \\
\text { kalkıp dolaşma isteği geliyor hatta neredeyse ders } \\
\text { başladıktan sonra yarım saat kadar sonra mutlaka } \\
\text { kaç dakika kalmış diye saate bakıyorum. Nedeni } \\
\text { de bence insan beyninin aktifliği bir süre sonra } \\
\text { aynı şeyle meşgul olmak istemiyor. Çünkü ders } \\
\text { dinlerken gerek konuyla alakalı gerek alakası, } \\
\text { yapabileceğimiz başka şeyler geliyor aklımıza ve } \\
\text { onları yapmak istiyor sanırım beynimiz biraz may- } \\
\text { mun iştahlı. (SK6) } \\
\text { Sürekli ders ne zaman bitecek, sıkıldım diye saate } \\
\text { bakarım, dikkatimi derse veremem. (HEK1) }\end{array}$ & $\begin{array}{l}\text { HK1, HK2, HK3, } \\
\text { HK8, PK3, PK6, } \\
\text { TK6, TK7, UK5, } \\
\text { TÜK3, TÜK5, } \\
\text { TÜK6, TÜK7, } \\
\text { TÜK8, İK6, HEK2, } \\
\text { VK2, VK7, DK2, } \\
\text { DK3, DK4, DK5, } \\
\text { BK2, BK5, BK8, } \\
\text { SAK1, SAK6, } \\
\text { MK2, SK2, SK5 }\end{array}$ \\
\hline$\dot{I} \lg i$ & $\begin{array}{l}\text { Dersi dikkatli dinleme sürem benim derse olan } \\
\text { ilgime bağli. Sevmediğim dersi ilk } 10 \text { dakika din- } \\
\text { lesem de ilgimi çekmediği için dikkatim başka } \\
\text { yerlere gidiyor ve dersi kaçırıorum bir daha da } \\
\text { adapte olamıyorum. (PK1) } \\
\text { Çoğu zaman dersin bana katacaklarına ve ilgi } \\
\text { çekiciliğine göre hareket ederim. Eğer ders benim } \\
\text { ilgimi çekiyorsa dersi sonuna kadar dinlerim. } \\
\text { (İK8) } \\
\text { Sevdiğim ya da anlamakta zorlanmadığım dersleri } \\
\text { daha uzun süre dikkatle dinleyebiliyorum. (SAK5) }\end{array}$ & $\begin{array}{l}\text { PK8, TK2, UK2, } \\
\text { UK3, UK7, UK8, } \\
\text { AK6, IK } 3, \text { IK } 5, \\
\text { HEK5, HEK7, } \\
\text { VK4, VK5, VK8, } \\
\text { DK1, DK7, BK1, } \\
\text { BK7, SAK2, MK3, } \\
\text { MK7, SK3, SK7 }\end{array}$ \\
\hline
\end{tabular}




\begin{tabular}{|c|c|c|}
\hline Öğretmen & $\begin{array}{l}\text { Hocadan hocaya değişiyor. Örneğin bir derste } 1.5 \\
\text { saat boyunca full dikkat dinleyebiliyorken başka } \\
\text { bir derste } 30 \text {. dakikadan sonra dikkatim dağılıor. } \\
\text { Bunun nedeni olarak hocanın anlatı̧ tarzı ve öğ- } \\
\text { renciyi aktif tutması diye düşünüyorum. (HK6) } \\
\text { Dersi anlatan hocaya bağlı, hoca kendi dersine ne } \\
\text { kadar saygı gösteriyorsa, ne kadar önem gösteri- } \\
\text { yorsa, o ne kadar istekli anlatırsa ben de dinlemeye } \\
\text { o kadar istekli olurum. (PK7) } \\
\text { Aslında genellikle dersine bağlı. Full bilgi veren } \\
\text { hocayı çok dikkatli bir şekilde dinleyemiyorum. } \\
\text { En fazla yarım saat. Yarım saatten sonra aklım } \\
\text { karışıyor. Çünkü anlattıklarını algılamaya, haya- } \\
\text { tımda gerçekleştirmeye ve yerine oturtmaya ça- } \\
\text { liş1yorum. Bu yüzden biraz zorlanıyorum. Ama } \\
\text { karşılıklı konuşma şeklinde işlenen derslerimizde } \\
\text { genellikle aktif bir şekilde } 50 \text { dakika bile dinledi- } \\
\text { ğim oluyor. Daha sonrasında dikkatim dağılıyor, } \\
\text { saate bakıyorum ve dersin bitiş süresini hesapla- } \\
\text { maya çalışıyorum. (SK1) }\end{array}$ & $\begin{array}{l}\text { PK4, AK1, AK3, } \\
\text { AK4, AK7, AK8, } \\
\text { TÜK2, TÜK4, } \\
\text { İK4, İK7, HEK8, } \\
\text { VK3, BK3, BK4, } \\
\text { BK6, SAK4, } \\
\text { MK1, MK4, } \\
\text { MK5, MK6, } \\
\text { MK8, SK4 }\end{array}$ \\
\hline $\begin{array}{l}\text { Ders } \\
\text { süreci }\end{array}$ & $\begin{array}{l}\text { Bu biraz da ders süresine bağlı. Eğer ders } \\
\text { blok olursa bilgi yoğunluğundan dolayı en } \\
\text { fazla bir saat dinleyebiliyorum. (HK4) } \\
\text { Uygulamalı dersleri son dakikasına kadar } \\
\text { dinleyebiliyorum. Teorik derslerin son daki- } \\
\text { kalarını dinleyemiyorum. Çünkü çok sıkılı- } \\
\text { yorum. (TK3) }\end{array}$ & $\begin{array}{l}\text { HK5, PK2, PK5, } \\
\text { AK2, AK5, İK1, } \\
\text { İK2, HEK3, VK1, } \\
\text { DK8, SAK8 }\end{array}$ \\
\hline $\begin{array}{l}\text { Fiziksel } \\
\text { ihtiyaçlar }\end{array}$ & $\begin{array}{l}30 \text { dakika dikkatli dinleyebiliyorum. Son } 15 \\
\text { dakikasını anlamıyorum. Çünkü sigara içme- } \\
\text { ye ihtiyaç duyuyorum. Bu yüzden odaklana- } \\
\text { mıyorum. (TÜK1) } \\
\text { Sabah erken olan dersleri pek takip edemiyo- } \\
\text { rum. Uykum oluyor, zorlanıyorum. (DK6) }\end{array}$ & $\begin{array}{l}\text { TK4, TK5, TK8, } \\
\text { UK1, UK4 }\end{array}$ \\
\hline
\end{tabular}




\begin{tabular}{lll}
\hline \hline & & \\
\hline & Bazen bir sıkıntım oluyor. Ailevi, yurttaki oda ar- & TK1, HEK6, \\
& kadaşlarımla. Kafama çok takıyorum ve ders din- & SAK7 \\
& leme sürem azalıyor. (UK6) & \\
Psikolojik & O günkü psikolojime göre değişir esasında. Kafam & \\
durum & başka şeylere takılmışsa, onun etkisinden kur- & \\
& tulmak için biraz savaş veririm kendimle. Çoğu & \\
& zaman bu savaşı başaramam ve dersten koparım. & \\
& (HEK4) & \\
\hline \multirow{3}{*}{ Ortam } & Ders dinleme kalitem sınıfta oturduğum yere göre & İK4, SK8 \\
& farklılık gösterir. Yani hocanın gözünün önünde & \\
& olmam gerekir. (VK6) & \\
\hline
\end{tabular}

Tablo 2'de "Bir ders süresince ne kadar dikkatli dinleyebilirsiniz? Nedenleriyle açıklayabilir misiniz?" sorusu doğrultusunda elde edilen bulgular yer almaktadır. Katılımcıların dikkatli dinleme süreleri 10 ila 50 dakika arasında değişmektedir. Öğrencilerin dikkatli dinleme sürecini etkileyen unsurlar; dikkat dağınıklığı, ilgi, öğretmen, ders süreci, fiziksel ihtiyaçlar, psikolojik durum ve ortam olmak üzere 7 ana temada toplanmıştır. Sözel alanlardan 18, sayısal alanlardan 15 toplam 33 (\%30) katılımcı dikkat dağınıklığının dinleme süresini etkilendiğini ifade etmektedir. Derse olan ilginin süre üzerinde etkisi olduğunu belirten öğrenci sayısı 26'dır. Bu öğrencilerden 15'i sayısal bölümlerde öğrenim görmektedir. Öğretmen faktörüne vurgu yapan 25 katılımcının 12'si sözel bölümlere devam etmektedir. Ders sürecinin süre üzerinde bir değişken olduğunu belirten 13 katılımcı varken fiziksel ihtiyaçlar boyutunda 7 öğrenci bulunmaktadır. Psikolojik durumun etkisinden söz eden katılımcı sayısı 5 'tir. Dinleme sürecini etkileyen faktörler genel anlamda dinleyiciden kaynakl1, konuşmacıdan kaynaklı, dinleme anlama hızı, ortam şeklinde ifade edilmektedir. Dikkat, ilgi, fiziksel ihtiyaçlar, psikolojik durumlar dinleyiciye bağlı faktörler olarak değerlendirilebilir. Ancak katılımcıların gerçekliğini araştırma yapısına uygun olarak derinlemesine ortaya çıkarmak amaçlandığından ifade edilen kavramların her biri ayrı birer tema olarak ele alınmıştır. Dinleme ortamı da dinleme sürecini etkileyen temel unsurlar arasında yer almaktadır. Ancak araştırma kapsamında ortamın dinleme süresi üzerinde etkisi olduğunu düşünen katılımcı sayısı oldukça azdır (\%3). 
Katılımcıların ders dinleme süreçlerini etkileyen dinleme engellerinin neler olduğu da çalışmanın sınırları içerisinde belirlenmek istenmiş̧ir. Akademik dinleme sürecini etkileyen dinleme engellerinin kaynakları Tablo 3 'te temalaştırllarak ifade edilmiştir.

Tablo 3. Katılımcıların Karşılaştıkları Dinleme Engelleri

\begin{tabular}{cll}
\hline Tema & \multicolumn{1}{c}{ İfade edilen } & \multicolumn{1}{c}{$\begin{array}{c}\text { Katılan- } \\
\text { lar }\end{array}$} \\
\hline & Bence dersi dinlememi etkileyen faktör- & TK1, TK8, \\
& lerin en önemlisi ses tonu, hocanın sesi & UK1, UK6, \\
biraz yüksek olmalı. (AK2) & UK8, HK4, \\
& Hoca tane tane konuşarak dersi anlatsın. & AK5, AK8, \\
& Hatta diksiyonu düzgün olmayanı hoca & TÜK1, TÜK7, \\
& da yapmasınlar. (TÜK8) & PK3, PK4, PK5, \\
& Öğretmenin sınıfta bize karş1 sert ve agre- & SK2, IK2, IK8, \\
& sif tavırları beni kasıyor ve o derse ilgim & HEK1, VK4, \\
& azalıor. (PK1) & VK8, DK1, \\
& Hocanın görüntüsü, ses tonu, üslubu ders & DK6, MK6 \\
& dinlememi etkiler.(DK3) & \\
& Erkek hocalar daha iyi. Kadın hoca olursa & \\
& dersi dinlemem. (BK1) & \\
& Hocaların hitabet kabiliyetlerini artırma- & \\
& ları gerekiyor. (SAK2) & \\
\hline
\end{tabular}


Sınıfın çok kalabalık ve havasız olması etkiliyor. İnsan bir süre sonra bunaliyor ve biran önce dersin bitmesini istiyor. Ayrıca çok gürültülü olması sınıfın herkesin bir anda konuşması da benim dikkatimi dağıttığı için ders dinlememi engelliyor. (PK6)

Duvardaki saat kaldırılmalıdır. Benim dikkatimi çok dağıtıyor. Ayrıca pencerelerin manzaralı olması da dikkatimi dağıtıyor, öyle olduğunda sürekli dışarı bakmak istiyorum. (TK3)

Sınıfın yoğunluğu, bazı derslere iki yüz kişi geliyor bu da sınıfın belli bir zaman

Ortam sonra havasız kalmasına neden oluyor. (HK1)

Dersliğin koyu renkli bir boyayla boyalı olması. (AK7)

Başta sınıf ortamı, 1sısı, ışık yeterliliği, dışarıdan gelen etkenler yani gürültü, fazla 1 şı veya pis koku dinlememi olumsuz etkiler. (TÜK4)

Giriş katında işlediğimiz derslerde dışarıdan gelen sesler (yan taraftaki inşaat) dinlememi olumsuz etkiler. (İK1) Sınıf çok sıcak olursa mayışıyorum olmuyor, çok soğuk olursa üşüyorum olmuyor. Ne çok sicak ne de çok soğuk olacak (DK5)
TK2, TK4, TK5, HK6, HK8, TÜK2, TÜK3, TÜK5, TÜK6, PK8, SK6, İK4, İK5, İK6, İK7, HEK7, VK1, DK2, DK4, BK2, BK5, SAK3, SAK8, MK2, MK5, MK7 


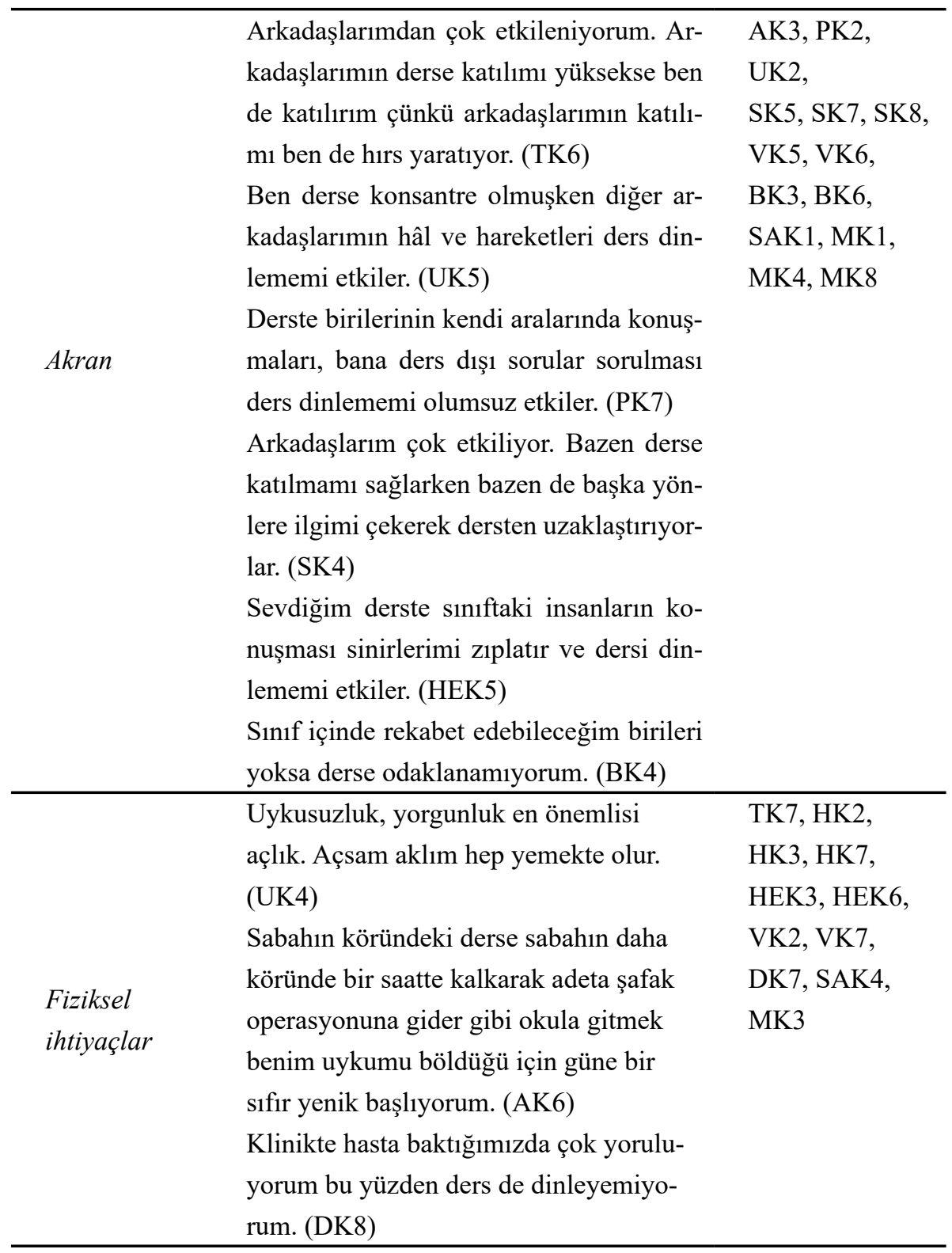




\begin{tabular}{|c|c|c|}
\hline $\begin{array}{l}\text { Ders } \\
\text { içeriği }\end{array}$ & $\begin{array}{l}\text { Dersin niteliği, içeriği benim için önemli } \\
\text { bir faktördür. Bazı derslerin konuları hiç } \\
\text { ilgimi çekmiyor. Hele o konuyla ilgili } \\
\text { bilgim de yoksa dinlemem. (UK3) } \\
\text { Bir dersin dinlenip dinlenmemesi hangi } \\
\text { ders olduğuna bağlı. (SAK5) }\end{array}$ & $\begin{array}{l}\text { UK7, AK4, İK3, } \\
\text { SAK6, SK3 }\end{array}$ \\
\hline $\begin{array}{l}\text { Ders dışı } \\
\text { uyaranlar }\end{array}$ & $\begin{array}{l}\text { Derste telefonuma odaklanmam dikkati- } \\
\text { mi dağıtıyor. (HK5) } \\
\text { Önümde güzelim telefonum dururken } \\
\text { ders hiç de cazip gelmiyor. (AK1) } \\
\text { Altta telefon titrerken illaki elimiz telefo- } \\
\text { na gidiyor. Elimize almışken de kimden } \\
\text { mesaj gelmiş, kim ne fotoğraf atmış diye } \\
\text { bir ansa kendimizi internette gezerken bu- } \\
\text { luyoruz. (HEK8) }\end{array}$ & $\begin{array}{l}\text { HEK2, HEK4, } \\
\text { BK7, BK8, } \\
\text { SAK7, SK1, } \\
\text { VK3 }\end{array}$ \\
\hline
\end{tabular}

"Ders sürecinde ne tür dinleme engelleri ile karşılaştığınızı düşünüyorsunuz? Bu konudaki görüşlerinizi paylaşır mısınız?” sorusuna ilişkin toplanan bulguların sunulduğu Tablo 3 'te katılımcıların akademik dinleme süreçlerindeki dinleme engellerinin ortaya çıkarılmasına odaklanılmıştır. Tablo 3 incelendiğinde öğretmen, akran, ortam, fiziksel ihtiyaçlar, ders içeriği ve ders dışı uyaranlar olmak üzere 6 tema etrafinda dinleme engelleri kategorileştirilmiştir. Çalışma kümesinde yer alan 33 öğrenci, ortamın nasıl bir dinleme engeline dönüştüğünü dile getirmiştir. Sınıfın fiziksel koşullarının yanı sıra sınıf mevcudunun da öğrenci üzerinde dinleme açısından olumsuz ne tür engellere neden olacağı öğrenci görüşleri doğrultusunda ortaya konmuştur (Sinıfin çok kalabalık ve havasız olması etkiliyor. Insan bir süre sonra bunallyor ve biran önce dersin bitmesini istiyor. Ayrıca çok gürültülü̈ olması sınıfin herkesin bir anda konuşması da benim dikkatimi dağıttı̆̆ için ders dinlememi engelliyor. (PK6)) 28 katılımcı konuşmacı başka bir ifade ile öğretmen kaynaklı dinleme engelleri ile karşılaştığını belirtmektedir. Öğretmenin ses tonu, öğrenci-öğretmen etkileşimini gerçekleştirememesi gibi nedenler katılımcıların ders sürecindeki dinleme faaliyetlerini sekteye uğratmaktadır. Katılımcıların akranlarından kaynaklı dinleme engelleri yaşaması, araştırma 
kapsamında ulaşılan dikkat çekici bir bulgu olarak yorumlanmıştır. 20 katılımcı akran davranışlarının dinleme sürecini olumsuz etkilediğini ifade etmiştir. Dinleyicinin fiziksel ihtiyaçları (açlık, uyku vb.), derse yönelik ilgisi ve ders dişı uyaranlar başlığı altında da özellikle cep telefonu kullanımı birer dinleme engeli olarak belirtilmiştir.

Araştırma kapsamında derste dinleme verimliliğini artırmak, bir bakıma akademik dinleme engellerini ortadan kaldırmak için neler yapılabileceği de sorgulanmıştır. Elde edilen bulgular Tablo 4 'te gösterilmiştir.

Tablo 4. Katılımcıların Dinleme Verimliliğini Artırmaya Yönelik Önerileri

\begin{tabular}{|c|c|c|}
\hline Tema & Ífade edilen & Katılanlar \\
\hline Öğretmen & $\begin{array}{l}\text { Öğretmenlerin öğrencilerle kurduğu dostane } \\
\text { ilişkilerle ders zevkli bir hâle gelebilir. (TK1) } \\
\text { Hocalar öğrencilerin daldığını fark ettiği zaman } \\
\text { küçük espriler yapıp onların dikkatlerini üzerle- } \\
\text { rine çekmeli, dersi öğrenci ile soru cevap şeklin- } \\
\text { de işlemeli. (TÜK1) } \\
\text { Hocanın etkin iletişim kurması, öğrenci odaklı } \\
\text { olması gerekiyor. (HK1) } \\
\text { Öncelikle öğretmen dediğin somurtmayacak } \\
\text { arkadaş. Kişisel hayatı, askerlik hayatı bizi hiç } \\
\text { de ilgilendirmez. Bunun yerine ders konumuzla } \\
\text { ilgili dikkatimizi çekecek bir üslupla anlatabilir. } \\
\text { (AK1) } \\
\text { Hoca tatlı tatlı adeta bir çikolata şelalesi olur- } \\
\text { casına tatlı dersi anlatarak dersin sıkıcı havasını } \\
\text { bozmalıdır. (AK6) } \\
\text { Öğretmenlerimiz put gibi oturdukları yerden } \\
\text { kalkmazsa, uyuşuk ses tonuyla anlatırsa } \\
\text { herhâlde bizim de içimiz kıyılır. Bizimki de can. } \\
\text { ( HEK8) }\end{array}$ & $\begin{array}{l}\text { UK1, UK6, } \\
\text { UK7, TK3, } \\
\text { TK4, TK5, } \\
\text { PK4, PK5, } \\
\text { PK6, PK7, } \\
\text { PK8, TÜK4, } \\
\text { TÜK5, TÜK6, } \\
\text { TÜK7, TÜK8, } \\
\text { HK2, HK5, } \\
\text { HK7, HK8, } \\
\text { AK7, AK8, } \\
\text { İK1, IKK3, İK5, } \\
\text { İK6, IK7, } \\
\text { HEK2, HEK3, } \\
\text { HEK5, VK2, } \\
\text { VK3, VK6, } \\
\text { VK7, VK8, } \\
\text { DK7, BK1, } \\
\text { BK2, BK3, } \\
\text { BK6, BK7, } \\
\text { BK8, SAK1, } \\
\text { SAK3, SAK4, } \\
\text { MK2, MK3, } \\
\text { MK4, MK5, } \\
\text { MK7 }\end{array}$ \\
\hline
\end{tabular}




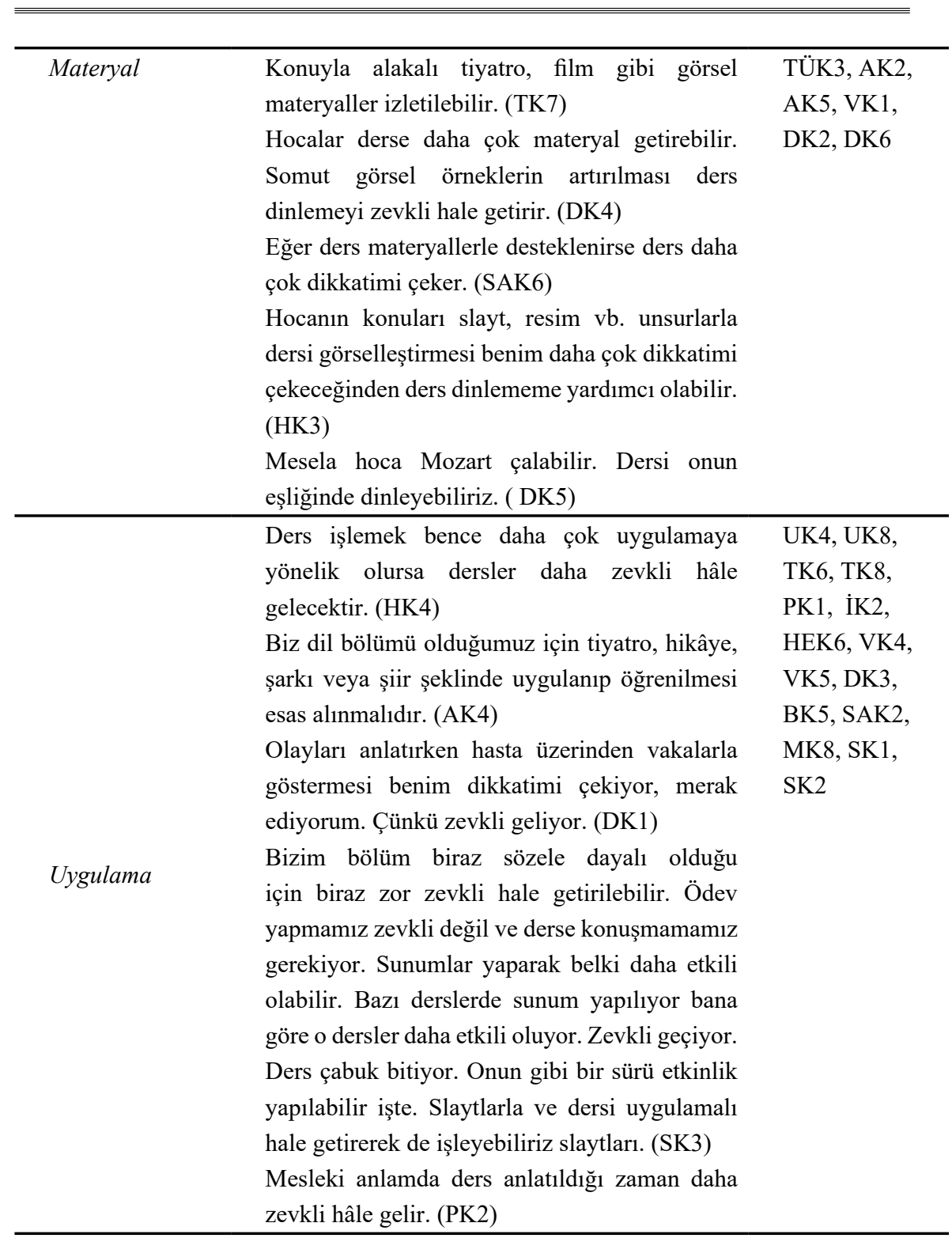




\begin{tabular}{|c|c|c|}
\hline $\begin{array}{l}\text { Gündelik hayatla } \\
\text { ilişsilendirme }\end{array}$ & $\begin{array}{l}\text { Tarih derslerinde uygarlık tarihi olsun, siyasi } \\
\text { tarih olsun bu olayları anlatan müzeler daha } \\
\text { yakından tanınabilir ya da bu olaylara tanıklık } \\
\text { etmiş insanlar dinlenebilir. (UK3) } \\
\text { Konuyla ilgili haberlerden, güncel bilgilerden } \\
\text { veya yaş grubuna uygun konulardan bahsedip } \\
\text { örnek vererek ders anlatırsa zevkli olur. (PK3) } \\
\text { Ders kitaplarından değil de hayatımızda } \\
\text { karşılaştığımız olaylarla ilişkilendirerek dersin } \\
\text { verilmesi dersi zevkli hâle getirir. (AK3) } \\
\text { Sürekli ders amaçlı değil de gerçek hayatta } \\
\text { işimize yarayabilecek bilgilerin araya } \\
\text { sikıştırılmas1 dersi daha ilgi çekici hâle } \\
\text { getiriyor. (SK6) }\end{array}$ & $\begin{array}{l}\text { HK6, İK4, } \\
\text { BK4, MK1, }\end{array}$ \\
\hline $\begin{array}{l}\text { Ögrenci } \\
\text { merkezli }\end{array}$ & $\begin{array}{l}\text { Öğrencilerin duygu ve düşüncelerini ifade } \\
\text { edebileceği bir anlatım varsa daha zevkli } \\
\text { olabilir. (UK5) } \\
\text { Derste öğrencinin söz alıp katıldığı dersler bir } \\
\text { başkadır. Dersin akışı hızlanır. (IKK8) } \\
\text { Herkesin ilgi alanına göre dersler konulsa yani } \\
\text { kişiye özel ders uygulaması gibi bir şey olsa, } \\
\text { öğrenciler zaten otomatik olarak dersi zevkli } \\
\text { bulur. (SAK5) } \\
\text { Hocalar öğrencilerin anlayabileceği şekilde } \\
\text { örnekler vermeli. Hoca; şurayı çizin, şurayı not } \\
\text { alın demeli. (MK6) }\end{array}$ & $\begin{array}{l}\text { TK2, SAK8, } \\
\text { SK8 }\end{array}$ \\
\hline Strateji & $\begin{array}{l}\text { Ders dinlemek bence not tutarak zevkli hâle } \\
\text { gelebilir. Not tutmazsam zaten bir süre sonra } \\
\text { başka şeyler düşündüğümü fark ediyorum. } \\
\text { (TÜK2) } \\
\text { Küçük, gözüme hitap eden düzenli } \\
\text { kullanabileceğim bir not defteri ve renkli } \\
\text { kalemlerle bile ders benim için zevkli hale } \\
\text { gelebilir. (HEK4) }\end{array}$ & $\begin{array}{l}\text { DK8, SK7, } \\
\text { HEK1, HEK7, } \\
\text { SAK7, SK4, } \\
\text { SK5, UK2 }\end{array}$ \\
\hline
\end{tabular}

Tablo 4’te "Sizce ders dinleme verimliliği nasıl artırlabilir?” sorusu çerçevesinde ulaşılan bulguların temalaştırılmış hâli bulunmaktadır. Buna göre katılımcılar ders verimliliğinin artırılmasında öğretmenin temel unsur olduğunu 
düşünmektedir (56 (\%50) katılımcı). Bu görüş etrafında birleşen katılımcıların alan dağılımının birbirine çok yakın olduğu görülmektedir (27 sözel 29 sayısal). Öğretmen faktörüne bağlı olarak derslerin teoriden ziyade uygulamaya dayalı işlenmesini öneren katılımcı sayısı 20' dir. Sözel bölümlerde uluslararası ilişkiler ve tarih, sayısal alanlarda ise mühendislik ve veterinerlik öğrencilerinin böyle bir talebi ifade ettiği anlaşılmaktadır. Uygulamalı ders talebinin yanı sıra katılımcılar derslerde materyal kullanımının önemine de vurgu yapmaktadır (TÜK3, HK3, AK2, AK5, VK1, DK2, DK5, DK6, SAK6 TK7 DK4). Öğrenciyi merkeze alan derslerin düzenlenmesinin ders verimini artıracağını ifade eden öğrenci sayısı 7'dir. Bunun için öğrencilerin kendilerine de sorumluluk yüklediği gözlenmiştir. Çeşitli stratejiler kullanmaları gerektiğini dile getiren katılımcı sayısı 9'dur. Bu bulgu doğrultusunda öğrencilerin "Dinleme stratejik olmalıdır." ilkesine uygun hareket ettiği söylenebilir. Bu anlamda ulaşılan bulgular incelendiğinde katılımcıların "not alarak dinleme" stratejisi üzerinde yoğunlaştığı görülmektedir. Yine öğrenciler, ders sürecinde öğretilenlerin gündelik hayatla ilişkilendirilmesini istemektedir (HK6, İK4, BK4, MK1, SK6 UK3 PK3 AK3).

Son aşamada çalışma kümesinin kendilerini akademik dinleyici olarak niteleme düzeyleri incelenmiştir. Ulaşılan bulgular Şekil 1'de ifade edilmiştir.

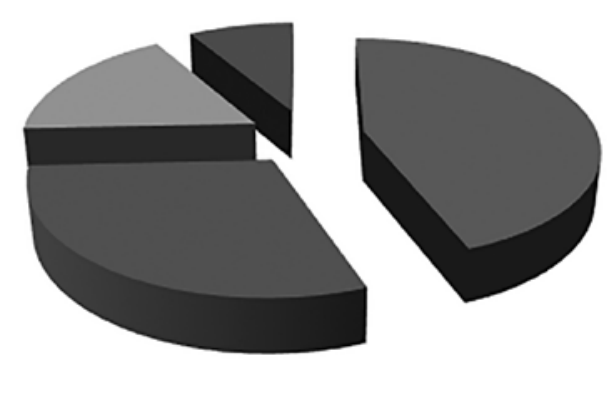

1. Akademik dinleme becerisine sahip değilim.

a2. Akademik dinleme beceri düzeyim i bilm iyorum.

3. Akademik dinleme becerim orta düzeydedir.

a 4. Çok iyi düzeyde akademik dinleme becerisine sahibim.

Şekil 1. Üniversite ögrencilerinin akademik dinleme becerisi düzeyleri

Şekil 1 incelendiğinde akademik dinleme becerisine sahip olmadığını düşünen kat1lımc1 (PK2, PK3, PK5, PK8, HK1, HK2, HK3, HK4,HK5, HK6, IK1, İK2, İK3, İK4, İK6, İK7, İK8, HEK2, HEK3, HEK4, HEK5, HEK6, HEK7, HEK8, VK1, VK2, VK3, VK4, VK7, VK8, DK2,DK5, BK3,BK5, SAK1, SAK4, 
SAK7, MK2, MK3, MK4, MK5,MK6) sayısının oldukça fazla olduğu görülmektedir (42). Bu temadaki katılımcıların büyük çoğunluğunun sayısal bölümlere devam eden öğrencilerden olması dikkat çekmektedir (30). Özellikle hemşirelik, inşaat mühendisliği ve makine mühendisliğinde okuyan öğrencilerin neredeyse tamamı akademik dinleme becerisi yönünden kendilerini yetersiz hissetmektedir. Üniversitenin mesleki bir eğitimi kapsadığı düşünüldüğünde ortaya çıkan tablonun oldukça olumsuz olduğu söylenebilir. Öğrencilerin neden bu şekilde düşündüklerine ilişkin örnek cümleler aşağıdadır:

"Arkadaşlarımla sohbet etmeyi seviyorum, ders dinlemek benim için işkence. Derste telefonuma gömülüp kim ne yapmış onları takip ediyorum. Sonra sınav zamanı da not toplama telaşına düşüyorum." (HK6)

"Derslere devam problemim var. Gidince nerdeydik, nerede kaldlk diye düşünmekten gittiğim dersi de dinleyemiyorum. Benim için ders devamsızlıktan kalmamak için yapılan bir görev." (İK6)

"Ben diş hekimliği okuyorum teori ile benim ne işim var. Neyi dinleyim? Bana diş lazım ki kendimi geliştireyim. Akademik dinlemeye değil akademik dişe ihtiyacım var benim." (DK2)

Görüldüğü gibi aynı görüş etrafında birleşen katılımcıların ders dinleme gibi bir kaygıları bulunmamaktadır. Dolayısıyla kendilerini akademik dinleme becerisine sahip olmadıkları yönünde değerlendirmektedirler.

Akademik dinleme becerisi düzeyini bilmediğini ifade eden öğrencilerin say1s1 36'dır (UK1, UK3, UK4, UK5, UK8, TÜK3, TÜK4, TÜK5, TÜK6, AK1, AK2, AK3, AK7, AK8, TK2, TK3, TK5, TK6, TK8, SK2, SK3, SK4, SK7, SK8, BK1, BK2, BK6, BK7, SAK2, SAK5, SAK6, SAK8, VK6, DK1, DK4, DK6). Bu durumun nedenleri sorgulandığında şu tür cevaplarla karşılaşılmaktadır:

"Akademik dinlemenin muhakkak kriterleri vardlr. Ben kriterleri bilmiyorum. Neye göre iyiyim neye göre kötüyüm değerlendiremediğim için yorumum yanlış olur.”

"Ben kendimi tanimiyorum ki akademik dinleme düzeyimi tanıyım. Hayat çok acıması insana kendini unutturuyor. Derse giriyorum ne kadar akademik dinliyorum bilmiyorum, kalyyorum geçiyorum, geçiyorum kalyyorum. Hayat böyle devam ediyor." 
"Şimdi iyiyim desem kendimi beğenmiş olacağım, kötü desem tembel olacağım bilmiyorum deyim bu arada gerçekten de bilmiyorum."

Akademik dinleme becerisinin orta düzeyde olduğunu ifade eden katılımcı say1s1 20'dir (SK1, SK5, TK1, TK7, HK7, PK1, PK6, TÜK7, TÜK8, AK5, AK6, MK7, MK8, İK5, HEK1, DK3, DK7, DK8, BK4, SAK3).Bu anlamda öğrencilerin "orta" ile ne kastettikleri de sorgulanmış; öğrenciler "ne iyi ne kötü” şeklinde kasıtlarını açıklamışlardır.

"Orta seviyede bir etkili dinleme becerim var bence. Çünkü dikkat dağınıklığım var. Dikkatim çabuk dağıllyor ve konsantre olamıyorum. Hele ki derslerde bilgi ă̆ır olduğu için yine dikkatim dağılabiliyor. Sosyolojide dinleme becerinizin olması gerekiyor. Fakat bende yok. Bu sosyoloji okuyanlar için zorluk teşkil edebiliyor. Sosyoloji bölümü yazanlara dinleme becerileri fazlaysa yazmaların öneriyorum." (SK5)

"Fifti fifiti desem yeridir. Niye derseniz kimi zaman tam bir ders kurduyum. Dinledikçe dinlerim kimi zaman amannnn bu ders nereden çıktı derim. Duruma göre değiştiği iç̧in ortalamayım yani." (HEK1)

"Hep ortalama bir öğrenci oldum, iyi de değildim kötü de değildim yine öyleyim. Öğrenciliğe dair ne varsa ortayım. Akademik dinlemede de ortayım, dümdüz." (MK7, AK7)

"Ders dinlerken beni etkileyen çok fazla şey var. Hocanin klyafeti bile dersi dinleyip dinlemeyeceğime karar vermem için yeterli. Bu kadar bıçak sirtına bağllyken dikkatim kendimi iyi olarak göremem." (TÜK8, BK6)

Araştırmada akademik dinleme düzeylerini "iyi" olarak niteleyen katılımc1 sayısının oldukça az olduğu (14) dikkat çekmektedir (TK4, HK8, PK4, PK7, UK2, UK6, SK6, TÜK1, TÜK2, AK4, MK1, VK5, DK1, BK8). Bu temada birleşen katılımcıların cevapları incelendiğinde akademik dinlemeye yönelik kendilerini doğru bir şekilde değerlendirdikleri anlaşılmaktadır:

"Kesinlikle iyi olduğunu düşünüyorum. Çünkü dinlemek için öncelikle çok konuşmayan insanların yanına oturmay tercih ediyorum. Daha sonra ders için gerekli araç ve gereçleri bulunduruyorum. Kitabım genelde yanımda oluyor dersle ilgili olarak. Not tutmayı çok seviyorum. Kendi tuttuğum notu anllyorum sade- 
ce. Bu yüzden not tutmak için elimden geleni yaplyorum. Not tutarken de dinleyip anlayarak not tutuyorum." (TÜK1)

"Bence çok iyiyim. Benim bölümüm sözel çok okumam, çok dinlemem gerekiyor. Tek başına okuma yeterli olmuyor aklımda kalmıyor. Derste dinlediklerim hiç aklımdan çıkmadiğı için derste çok dikkatli dinlerim, kendi kendime dinlediklerimi tekrar ederim." (UK6)

"Mezun olduğumda insana dayalı bir işim olacak ve bu iş tamamen dinlemeye yönelik. Karşımdakini dinlemeliyim ki onun derdine çare olabileyim, ona yardım edebileyim. Bu benim için çok önemli. Bu nedenle öncelikle benim iyi bir dinleyici olmam gerektiğini biliyorum ve çok gayret ediyorum. Ben gerçekten iyi bir dinleyiciyim diyorum." (PK7)

Görüldüğü gibi katılımcıların akademik dinleme düzeyleri bakımından kendilerine yönelik algıları farklılaşmakta ve katılımcıların büyük bir çoğunluğu akademik dinleme becerisi bakımından kendilerini yetersiz görmektedir.

\section{Sonuç ve Tartışma}

Üniversite eğitimine devam eden öğrencilerin akademik dinleme becerilerine yönelik yeterlik düzeylerine ilişkin algılarını belirlemeyi amaçlayan bu çalışmada 112 üniversite öğrencisinden elde edilen bulgulardan hareketle araştırmada şu sonuçlara ulaşılmıştır:

1. Katılımcıların bir dersi dikkatli dinleme süreleri 10 ila 50 dakika arasında değişmektedir. Dikkatli dinleme süreci üzerinde dikkat dağınıklı̆̆ı, derse yönelik ilgi, öğretmen, dinleyicinin fiziksel ve psikolojik gereksinimleri, ders süreci ve ortam önemli değişkenler olarak belirtilmektedir.

2. Akademik dinleme becerilerini sekteye uğratan dinleme engellerini katılımcılar; ortam, öğretmen, akran, fiziksel ihtiyaçlar, dersin konusu ve ders dışı uygulamalar şeklinde ifade etmektedirler.

3. Katılımcıların akademik dinleme verimliliğini artırmaya yönelik önerileri şu şekilde maddelenebilir:

a. Dersten sorumlu hoca, öğretmen-öğrenci etkileşimini sağlamalı.

b. Dersin içeriğine uygun çeşitli materyallerle konunun anlatımı zenginleştirilmeli. 
c. Dersin içeriği teorik bilginin aktarımından ziyade konunun yapısına uygun öğrencinin yapacağı uygulamalar esasına dayalı işlenmeli.

d. Derste verilen bilgiler, gündelik hayatla ilişkilendirilerek sunulmalı.

e. Öğrencilere dinlemeye yönelik strateji eğitimi verilmeli. Dinleme amacına göre işine yarayacak stratejiyi öğrenci seçip ders sürecinde kullanmalı.

f. Yeni bilginin sunumunda öğrencinin ön bilgilerinden hareket edilmeli.

4. Katılımcılar akademik dinleme becerisi düzeyi bakımından kendilerini genel anlamda yetersiz görmektedirler. Yeterli olduğunu düşünen sadece 14 (\%13) üniversite öğrencisi bulunmaktadır.

Ulaşılan sonuçlar dinleme sürecinin bileşenleri etrafında Şekil 2'de özetlenmektedir.

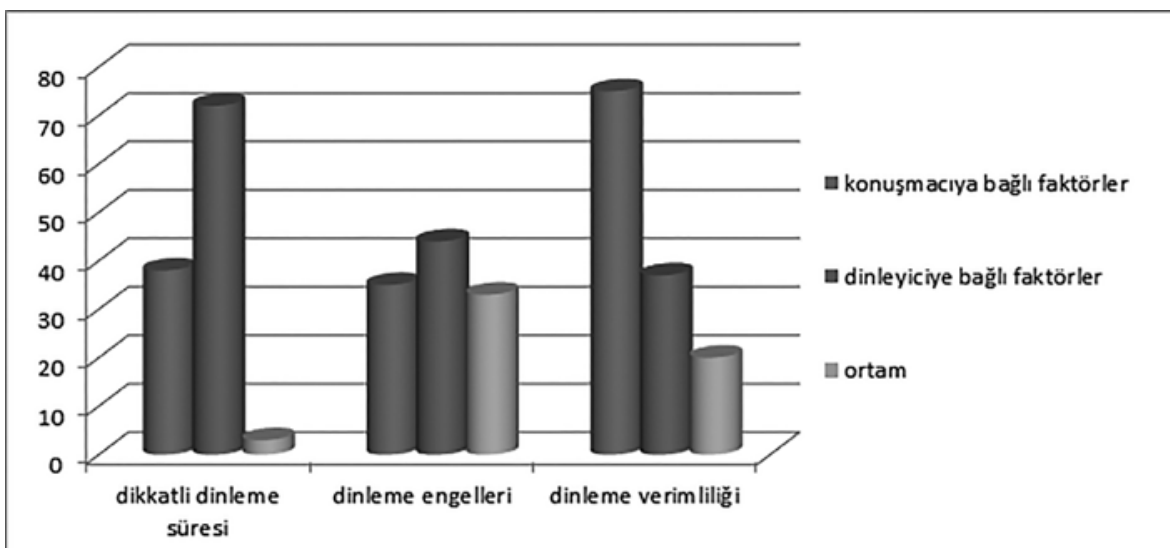

Şekil 2. Akademik dinleme sürecini alt boyutlarda etkileyen faktörler

Şekil 2 incelendiğinde dikkatli dinleme süresi üzerinde dinleyiciye bağlı faktörler önemli bir rol üstlendiği görülmektedir. Öğrencinin dersin içeriğine yönelik ön bilgisinin olmaması, bilgi eksikliği, derse ilişkin hazırbulunuşluğa sahip olmaması gibi etmenler dinleme-anlama hızını da etkilemekte ve bu, akademik dinlemede karşılaşılan bir soruna dönüşmektedir. İlgi ve ihtiyaçlar da akademik dinleme becerisinin gelişimi ve buna yönelik verilen eğitimin özelliğini belirlemektedir. Özbay (2005), öğrencilerin derste anlatılan konuya ilgi duymamaları veya konunun ihtiyaçlarını karşılamama durumlarında dinlemeyi sonlandırdık- 
larını ifade etmektedir. Ayrıca ders sürecinde öğrencinin ihtiyaç duyduğu bilgiyi seçebilmesi için öğretmen, derse başlamadan önce "Neden dinliyorum?" sorusunu öğrenciden kendince cevaplamasını isteyerek onun dinleme amacı belirlemesine rehberlik edebilir. Böylece dersin verimli geçmesi sağlanabilir.

Dinleme, psikolojik ve sosyal faktörlerden çok etkilenen bir iletişim unsurudur. Alınan mesajların özelliğine, mesaj kaynağının görsel davranışlarına, iletişim aracının (ses) nasıl kullanıldığına, dinleyenin hangi maksatla dinlediğine ve daha pek çok faktöre göre dinlemenin niteliği de değişebilir (Çiftçi 2001). Değişen dinleme niteliği, öğrencinin dinlemeye yönelik olumlu veya olumsuz tutum geliştirmesine yol açmaktadır. Dinleme gibi alıcı becerilerin kullanımı esasına dayanan derslerde öğrenciler süreçten kolayca kopmakta, bu durum da öğrencilerin kendilerini başarısız hissetmelerine neden olmaktadır (Goh, Meng ve Taib 2006: 230). Bunun için öğrencilere dinleme görevlerinde olumlu dönütler verilmeli veya onların eksikliklerini gidermeye yönelik uygulamalar yapılmalıdır. Graham (2006)'a göre görevler başarıll, etkili dinleme becerilerinin gelişimi için çok önemlidir ve bu, dinlemeye yönelik strateji eğitiminin verilmesi ile de yakından ilişkilidir. Böylece öğrencilerin maruz kaldıkları girdileri anlama yeteneklerine güvenmeleri neticesinde dinlemedeki öz-yeterlilikleri artacak ve akademik dinleme becerileri gelişecektir.

Dikkatli dinleme süresi ve dinleme engelleri boyutunda da öğretmen faktörünün önemli bir değişken olduğunu ifade eden katılımcılar, akademik dinleme verimliliğini artırmada da konuşmacıya başka bir ifade ile öğretmene önemli sorumluluklar yüklemektedir. Dinleme becerisi, birtakım meslekler için günlük hayattaki temel gereksinimden öte bir öneme sahiptir. Bu mesleklerin başında hemen her gün, uzun saatler öğrencilerle etkileşim içinde bulunulan öğretmenlik gelmektedir. Baysen vd. (2003: 54), öğretmenlerin öğretim programının yükümlülüklerini yerine getirmek için ders sürecini çok hızlı bir şekilde tamamladıklarını bu nedenle öğrenciye uygun dinleme davranışları sergileyemediklerini ifade etmektedir. Cangelosi (2013) yaptığı araştırmada öğretmenlerin yaklaşık \%11' inin öğrencilere övgü ve takdir içeren geri bildirim verdiğini, öğretmenlerin dörtte birinin ise öğrencilere hiçbir zaman övgü içeren geri bildirim vermedikleri sonucuna ulaşmıştır. Dinleme becerisinin geliştirilmesi konusunda ilkokuldan 
üniversiteye kadar öğrencilere "Dikkat et!", “Dinle!” gibi yönlendirici kalıp ifadeler dışında geliştirici bir ifade kullanılmadığı ve farklı uygulamalar yapılmadığı konuyla ilgili yapılan araştırmalarda vurgulanmaktadır (Nichols-Stevens 1974: 43). Oysa ders sürecinde öğrencilere "Seni anlıyorum, seni muhatap kabul ediyorum, sana değer veriyorum, sana sayg1 gösteriyorum." gibi içinde önemsenmenin bulunduğu mesajlar iletilmesi oldukça önemlidir (Deniz 2006). Maden (2013: 69)'e göre öğrencilerin zihnindeki dinleme imgesi “Sus, Susun, Dinleyin!" gibi ifadelerden ibarettir ayrıca sınıf ortamında gürültü olmadığında dinleme gerçekleşiyormuş, öğrenciler susunca dinliyorlarmış gibi bir algı yaygındır. Bu durum, öğretmenin yeterlik düzeyinin alt boyutlarda olduğunu göstermesi bakımından dikkat çekicidir. Özbay (2014: 169), öğretmenden kaynaklanabilecek dinleme engellerini; konuyu sunma biçimi, beden dili, jest ve mimikleri, ses tonu, bilgi birikimi ve Türkçeyi kullanma becerisi şeklinde sıralamaktadır ki katılımcıların öğretmen faktöründe ifade ettikleri hususlar da birebir bu maddelerle örtüşmektedir. Öğretmenin muhatabı öğrenciyle etkileşim sağlayabilmesi, ondan dönüt alabilmesi için öncelikle kendinin dinleme becerisine önem vermesi, dinleme sürecini nasıl yönetmesi gerektiğini bilmesi, karşılaştığı engellerde bunu nasıl ortadan kaldırması gerektiği noktasında bir kriz yönetimine sahip olması gerekmektedir. Ancak yapılan çalışmalar, durumun tam tersi sonuçlara sahiptir (Yangın 1994; Çaylı 2012; Melanlığlu 2013; Karabay 2014; Mete-Bağc1 Ayranc1 2016).

Dinleme engellerinde ortam unsuruna ayrılan orandaki artış dikkat çekmektedir. Ancak katılımcılardan dikkatli dinleme süresi üzerinde ortamın etkisine vurgu yapan oldukça az öğrenci bulunmaktadır. Dolayısıyla bu sonuç, katılımcıların akademik dinlemeye ilişkin görüşlerinin tam anlamıyla tutarlılık göstermediği şeklinde yorumlanabilir. Böyle bir durum, katılımcıların belki de kendi akademik dinleme süreçlerine ilişkin hiç düşünmemeleri ve kendilerine yönelik bir farkındalık geliştirememeleri ile ilişkilendirilebilir.

Mete ve Bağcı Ayrancı (2016) yaptıkları araştırmada lisans öğrencilerinin dinleme engellerini; can sıkıntısı, anlatılan içeriğin ilgi çekici olmaması, gerçek hayatla anlatılanların bağdaşmaması, öğretmenlerin konuya dikkat çekememesi ve sınıfların kalabalık olması şeklinde tespit etmişlerdir. Yapılan tespitler, bu araştırmanın sonuçları ile örtüşmektedir. Maden (2013: 51-78), yaptığı çalışmada 
"Neden dinlemiyoruz?" sorusuna cevap aramış ve dinlememeye yol açan etmenleri şöyle sıralamıştır:

- Özel yaşam alanı (aile) ve toplum yapısının dinleme üzerine etkisi

- Sözlü kültürden yazılı kültüre geçiş ve dinleme üzerine etkisi

- Eğitim geleneğimiz içinde dinleme becerisinin ihmali

- Kitle kültürü ve teknolojik yaşamın dinleme üzerine etkisi

Yapılan tasniften dinleme problemlerinin günlük yaşam temelli ele alındığı anlaşılmaktadır. Akkaya ve Ünal (2016: 71), dinlemeye engel olan faktörleri çevresel ve kişisel olarak ikiye ayırmaktadır. Çevresel faktörlere örnek olarak gürültü, amaca uygun düşmeyen sözel olmayan hareketler, fiziksel ortamın özellikleri sayılabilir. Dinlemeye engel kişisel etmenler ise öğrencinin algılama kapasitesi ve önceden edindiği olumsuz dinleme alışkanlıklarıdır. Emiroğlu (2013: 280-281), öğrenci görüşlerinden hareketle belirlediği dinleme problemlerini; göndericiden (konuşmacıdan) kaynaklanan sorunlar, alıcıdan (dinleyiciden) kaynaklanan sorunlar ve diğer sorunlar olmak üzere üç ana başlık altında ele almıştır. Adelmann (2012) "dinlemedeki geleneksel problemler" olarak dinleme sürecini, dinleme stratejilerini, dönütü, kavramayı ve değerlendirmeyi işaret etmektedir. Alanyazında dinlemeyi etkileyen unsurlar üzerine çeşitli sınıflamalar olsa da hepsinin içerikte birleştiğini söylemek mümkündür. Bu çalışmada dinleme becerisi akademik dinleme boyutu ile ele alınmış, üniversite öğrencilerinin akademik dinlemedeki yeterlik düzeyleri kendilerine yönelik farkındalıkları ile sunulmuştur. Üniversite öğrencilerinin akademik dinleme düzeylerinin yetersiz olduğu ulaşılan bulgular neticesinde ifade edilebilir. Bu, dinleme becerisinin gelişimi, toplumsal etkileşim vb. açılardan olumsuz bir durum olarak değerlendirilmektedir. Var olan bu olumsuzluğun giderilmesine yönelik şu önerilerde bulunulabilir:

1. Öğrenciler akademik dinleme becerilerini geliştirmeye yönelik herhangi bir eğitim almamaktadırlar. Bu becerinin gelişimi tamamen tesadüflere bırakılmaktadır. Üniversite 1. sınıfa başlayan her öğrenciye akademik dinleme dersi verilmesi için gerekli düzenlemeler yapılmalıdır.

2. Öğrencilerden akademik dinleme anlamında beklenenlerin yer aldığı bir kazanım tablosu hazırlanmalıdır. 
3. Akademik dinleme sürecini etkileyen faktörler bilinmekle birlikte bu faktörlerin ne ölçüde bir etki yarattı̆̆ıın belirlenmesi adına "Ders Dinleme Engelleri”ne ilişkin alt boyutları bakımından çeşitlendirilmiş ölçekler hazırlanmalı ve uygulanmalidir.

4. Konuyla ilgili deneysel çalışmalar yürütülerek süreci etkileyen, verimli alternatif yollar alanyazına kazandırılmalıdır.

5. Üniversite sınav sistemi nedeniyle öğrenciler sadece okuma becerilerindeki performanslarına göre tercihlerine yerleştirilmektedir. Bu durum, dinleme, konuşma ve yazma becerilerinin geri planda kalmasına yol açmaktadır. 4 beceriyi de ölçen bir sınav sisteminin akademik dinlemenin gelişimini destekleyeceği düşünülmektedir. 


\section{Kaynakça}

Adelmann, Kent (2012), "Eavesdropping As Listening Development”, International Journal of Listening Special Issue: Best Practices in the Teaching of Listening, C.26, S. 2, s. 91-93.

Akkaya, Nevin ve Ünal, Emre (2016), Sözlü Illetişim, Ankara: Anı Yayıncılık.

Aryadoust, Vahid, Goh, Christine C. M. ve Kim Lee Ong (2012), "Developing and Validating An Academic Listening Questionnaire", Psychological Test and Assessment Modeling, C.5, S. 4, s. 227-256.

Balay, Refik ve Sağlam, Miraç (2008), "Sınıf İçi Olumsuz Davranışlara İlişkin Öğretmen Görüşleri”, Yüzüncü Yıl Üniversitesi, Eğitim Fakültesi Dergisi, C. V, S.II, 1-24.

Başkan, Özcan (2003), Bildirişim, İstanbul: Multilingual Yayınları.

Baysen, Engin, Soylu, Hüseyin ve Baysen, Fatma (2003), "Soru Sorma ve Dinleme Süresi", Kastamonu Eğitim Dergisi, C. 11, S. 1, s. 53-58.

Brown, Gillian (2011), Listening to Spoken English, UK: Routledge Publishing.

Brown, Gillian ve Yule, George (1983), Discourse Analysis, New York: Cambridge University Press.

Burley-Allen, Madelyn (1995), Listening The Forgotten Skill, John Wiley and Sons, Inc.

Cangelosi, James S. (2013), Classroom Management Strategies. USA: John Wiley\&Sons Inc. Cihangir, Zeynep (2004), Kişilerarası İletişimde Dinleme Becerisi, Ankara: Nobel Yayınevi.

Cramer, Ronald L. (2004). The Language Arts A Blanced Approach to Teaching Reading, Writing, Listening, Talking and Thinking. USA: Pearson Education Inc.

Cüceloğlu, Doğan (2011), Mış Gibi Yaşamlar, İstanbul: Remzi Kitabevi.

Cüceloğlu, Doğan (2016), İnsan İnsana, İstanbul: Remzi Kitabevi.

Çaylı, Ceyda (2012), İlköğretim İkinci Kademe Türkçe Dersi Öğretmen Kılavuz Kitaplarındaki Müstakil Dinleme Metinlerine Yönelik Öğretmen Uygulamalarının Değerlendirilmesi, Kayseri: Erciyes Üniversitesi Eğitim Bilimleri Enstitüsü: (Yayınlanmamış Yüksek Lisans Tezi).

Çifçi, Musa (2001), “Dinleme Eğitimi ve Dinlemeyi Etkileyen Faktörler”, Afyon Kocatepe Üniversitesi Sosyal Bilimler Dergisi, C. 2, S. 2.

Danaoğlu, Gülsen (2009), Sinıf ve Branş Öğretmenlerinin İlköğretim 5. Sinıflarda Karşılaştıklarl İstenmeyen Davranışlar ve Bu Davranışlarla Baş Etme Stratejileri, Adana: Çukurova Üniversitesi Sosyal Bilimler Enstitüsü: (Yayımlanmamış Yüksek Lisans Tezi).

Deniz, M. Engin (2006), Sınıf İçinde İletişim, Sınıf Yönetimi, ed. Ramazan Arı ve M. E. Deniz, Ankara: Nobel Yayınc1lik.

Dökmen, Üstün (1994), İletişim Çatışmaları ve Empati, İstanbul: Sistem Yayıncılık. Egan, Gerard (2001), The Skilled Helper, Brooks Cole. 
Emiroğlu, Selim (2013), “Türkçe Öğretmeni Adaylarının Dinleme Sorunlarına İlişkin Görüşleri”, Adıyaman Üniversitesi Sosyal Bilimler Enstitüsü Dergisi Türkçenin Eğitimi Öğretimi Özel Sayısı, C. 6, S. 1.

Flowerdew, John (1995), Academic Listening Research Perspectives, England: Cambridge University Press.

Goh, Christine, Meng, Chuen ve Taib, Yusnita (2006), "Metacognitive Instruction In Listening For Young Learners", ELT Journal, C. 60, S. 3, s. 222-232.

Gordon, Thomas (1993), Etkili Öğretmenlik Ĕgitimi, çev. E. Aksoy ve B. Özkan, İstanbul: YaPa Yayınları.

Göğüş, Beşir (1978), Orta Dereceli Okullarımızda Türkçe ve Yazın Eğitimi, Ankara: Gül Yayınevi.

Graham, Suzanne (2006), "Listening comprehension: The learners' perspective”, System, S. 34, 165-182.

Jordan, R. R. (1997), English For Academic Purposes: A Guide And Resource Book For Teachers, London: Cambridge University Press.

Karabay, Ayşegül (2014), “Dinleme Metinlerinin Sınıf İçi Uygulamaları”, Hacettepe Üniversitesi Eğitim Fakültesi Dergisi, C. 29, S. 3, s. 81-94.

Lado, Robert (1961), Language Testing: The Construction and Use of Foreign Language Tests: A Teacher's Book. Bristol, Inglaterra: Longmans, Green and Company.

Lynch, Tony (2011). "Academic Listening in the 21st Century: Reviewing a Decade of Research", Journal of English for Academic Purposes, C. 10, S. 2, 79-88.

Maden, Sedat (2013), "Niçin Dinlemiyoruz?. Dinleyememe Probleminin Sosyokültürel Analizi”, Uluslararası Türkçe Edebiyat Kültür Eğitim Dergisi, C. 2, S. 1, s. 49-83.

Melanlığlu, Deniz (2012), "Dinleme Becerisine Yönelik Ölçme Değerlendirme Çalışmalarında Üstbiliş Stratejilerinin Kullanımı”, Turkish Studies, C. 7, S. 1, s. 1583-1595.

Melanlığlu, Deniz (2013), “Ortaokuldaki Dinleme Eğitiminin Niteliğine İlişskin Fenomografik Bir Araştırma”, Okuma Yazma Ĕgitimi Araştırmaları, 1 (1), s. 34-44.

Mete, Filiz ve Ayrancı Bağcı Bilge (2016), "Lisans Öğrencilerinin Dinleme Becerisi Üzerine Görüşleri”, Journal of Human Sciences, C. 13, S. 3, s. 4959-4972.

Moorhead, Robert ve Winefield, Helen (1991), "Teaching Coun-Seling Skills So Fourth-Year Medical Students: A Dilemma Concerning Goals", Family Practice, C. 8, S. 4, s. 343-346.

Nichols, Ralph ve Stevens, Leonard, A. (1974), "Dinleme Sanatı", Bilim Teknik, 80, s. 43-44.

Oğuzkan, A. Ferhan (1965), "Dinlemesini Bilmek”, İlköğretim, (31) s. 532.

Onan, Bilginer (2005), İlköğretim İkinci Kademe Türkçe Öğretiminde Dil Yapılarının Anlama Becerilerini (Okuma/ Dinleme) Geliştirmedeki Rolü, Ankara: Gazi Üniversitesi Eğitim Bilimleri Enstitüsü: (Yayımlanmamış Doktora Tezi).

Özbay, Murat (2005), Bir Dil Becerisi Olarak Dinleme Eğitimi, Ankara: Öncü Kitap.

Özbay, Murat (2009), Anlama Teknikleri - II: Dinleme Eğitimi, Ankara: Öncü Kitap.

Özbay, M. (2014). Bir Dil Becerisi Olarak Dinleme Eğitimi. Ankara: Öncü Kitap. 

348 Deniz MELANLIOĞLU, Üniversite Öğrencilerinin Akademik Dinleme Becerileri Üzerine Bir
Araştırma: Ders Ne Zaman Bitecek? Sıkıldım!

Özgözgü Özer, Esin (2007), Lise Öğretmenlerinin İstenmeyen Davranışlarla Baş Etme Stratejileri, İzmir: Dokuz Eylül Üniversitesi Eğitim Bilimleri Enstitüsü: (Yüksek Lisans Tezi).

Peterson, Russ D. ve ve Karschnik, Jr. Kevin J. (2011), Coaching Communication, Austin: İspeak.

Purdy, Michael (1997), What is listening? In Michael Purdy and Deborah Borisoff (eds.) Listening in Everyday Life. A Personal and Professional Approach. Lanham, MD: University Press of America.

Richards, Jack C. (1983), “Listening Comprehension: Approach, Design, Procedure”, TESOL Quarterly, 17, s. 219-239.

Robertson, Arthur K. (2004), Etkili Dinleme, çev. S. Yarmal1, İstanbul: Hayat Yayınları.

Temur, Turan (2001), Dinleme Becerisi, Konu Alanı Ders Kitabı İnceleme Kılavuzu 1-8, Ankara: Nobel Yayınları.

Tolunay Kapucuoğlu, Aycan (2008), Sinıf Öğretmenlerinin Sinıfta Karşılaştıkları İstenmeyen Öğrenci Davranışları ve Bu Davranışlara Karşsı Kullandıkları Baş Etme Yöntemleri, Bursa: Uludağ Üniversitesi Sosyal Bilimler Enstitüsü: (Yayımlanmamış Yüksek Lisans Tezi).

Tompkins, Gail E. (2005), Language Arts and Pratice, New Jersey: California State University, Prentice-Hall Inc.

Tompkins, Gail E. (1998), Language Arts Content and Teaching Strategies, New Jersey: California State University, Prentice-Hall Inc.

Uluğ, Feyzi (1995), Okulda Başarı, İstanbul: Fevzi Yayınevi.

Umagan, Suat (2007), Dinleme, İlköğretimde Türkçe Öğretimi, ed. Kırkkılıç, Akyol, Ankara: PegamA Yayıncılık.

Vandergrift, Jamia L. (2007), "Recent Developments İn Second and Foreign Language Listening Comprehension Research", Language Teaching, 40, s. 191-210.

Yalçın, Alemdar (2002), Türkçe Öğretim Yöntemleri Yeni Yaklaşımlar, Ankara: Akçağ Yayınları.

Yangın, Banu (1994), İlkokul Öğretmenlerinin Türkçe Dersindeki Davranışları, Ankara: Hacettepe Üniversitesi Sosyal Bilimler Enstitüsü: (Yayınlanmamış Yüksek Lisans Tezi).

Yıldırım, Ali ve Şimşek, Hasan (2008), Sosyal Bilimlerde Nitel Araştırma Yöntemleri, Ankara: Seçkin Yayıncılık. 